\title{
El-Niño southern oscillation and rainfall erosivity in the headwater region of the Grande River Basin, Southeast Brazil
}

\author{
C. R. Mello ${ }^{1}$, L. D. Norton ${ }^{2}$, N. Curi ${ }^{3}$, S. N. M. Yanagi ${ }^{1}$, and A. M. Silva ${ }^{1}$ \\ ${ }^{1}$ Engineering Department, Federal University of Lavras, UFLA, C.P. 3037, \\ 37200-000, Lavras, MG, Brazil \\ ${ }^{2}$ USDA/ARS National Soil Erosion Research Laboratory, Purdue University, \\ 47907-2077, West Lafayette, IN, USA \\ ${ }^{3}$ Soil Science Department, Federal University of Lavras, UFLA, C.P. 3037 , \\ 37200-000, Lavras, MG, Brazil
}

Received: 8 November 2011 - Accepted: 20 November 2011 - Published: 7 December 2011 Correspondence to: C. R. Mello (crmello@deg.ufla.br)

Published by Copernicus Publications on behalf of the European Geosciences Union.
El-Niño southern oscillation and rainfall erosivity

C. R. Mello et al.

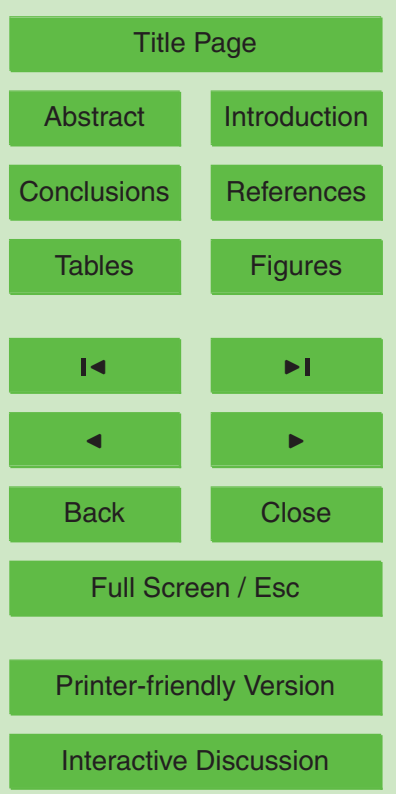




\section{Abstract}

Relationships between regional climate and oceanic and atmospheric anomalies are important tools in order to promote the development of models for predicting rainfall erosivity, especially in regions with substantial intra-annual variability in the rainfall 5 regime. In this context, this work aimed to analyze the rainfall erosivity in headwaters of Grande River Basin, Southern Minas Gerais State, Brazil. This study considered the two most representative environments, the Mantiqueira Range (MR) and Plateau of Southern Minas Gerais (PSM). These areas are affected by the El Nino Southern Oscillation (ENSO) indicators Sea Surface Temperature (SST) for Niño 3.4 Region and events from January 2006 to December 2010. The analyses were conducted using the monthly data of ENSO indicators and the following rainfall variables: rainfall erosivity $\left(\mathrm{El}_{30}\right)$, rainfall depth $(P)$, erosive rainfall depth $(E)$, number of rainfall events (NRE), number of erosive rainfall events (NEE), frequency of occurrence of an early rainfall pattern (EP), occurrence of late rainfall pattern (LP) and occurrence of intermediate rainfall patter (IP). Pearson's coefficient of correlation was used to evaluate the relationships between the rainfall variables and SST and MEI. The coefficients of correlation were significant for SST in the PSM sub-region. Correlations between the rainfall variables and negative oscillations of SST were also significant, especially in the MR sub-region, however, the Person's coefficients were lesser than those obtained for the SST positive oscillations. The correlations between the rainfall variables and $\mathrm{MEI}$ were also significant but lesser than the SST correlations. These results demonstrate that SST positive oscillations play a more important role in rainfall erosivity, meaning they were more influenced by El-Niño episodes. Also, these results have shown that the ENSO
HESSD

8, 10707-10738, 2011

El-Niño southern oscillation and rainfall erosivity

C. R. Mello et al.

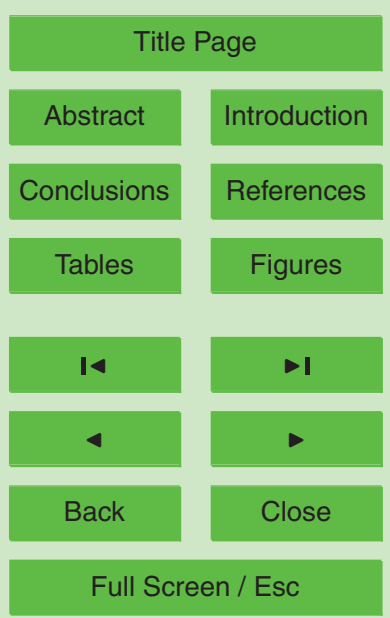

Printer-friendly Version

Interactive Discussion 


\section{Introduction}

Soil erosion is a major environmental problem in many countries around the world. Its origin is associated to several factors which can be classified as active or passive, being the latter increased by land-use characteristics, like agriculture, livestock farming and 5 mining. The active factor is controlled by the climate, like spatial and temporal rainfall distribution. Due to state-of-art knowledge of the Earth's climate (mainly those related to the atmospheric and oceanic anomalies), studies whose purpose is to investigate the existence of relationships between these anomalies and regional climate are possible. These data are especially important in order to give support for development of climatic or erosion forecasting models.

Rainfall erosivity is defined as the eroding power of raindrop impact (rain splash) and has been evaluated by many scientific investigations for many years. However, the rainfall erosivity investigations in Brazil have had as purpose the generation of simple mathematical models to estimate the mean monthly or annual rainfall erosivity of rainfall based on the Fournier coefficient (Renard and Freimund, 1993). These values were then used in the Universal Soil Loss Equation (USLE - Wischmeir and Smith, 1978) or models derived from it to provide basic information for soil and water resources management (Mello et al., 2007; Beskow et al., 2009; Barretto et al., 2009).

In tropical and sub-tropical regions, like Southeast and South Brazil, there is a significant intra-annual variability in rainfall due to specific climatic aspects which control the rainfall distribution. The South Atlantic Convergence Zone (SACZ), convective rainfall events, frontal systems (cold fronts), Cyclones and Anti-Cyclone of South Atlantic (ACSA) help to explain the rainfall regimes in Southeast Brazil (Reboita et al., 2010). These general climatic aspects cause high temporal rainfall variability and are characterized in a given year by an extremely rainy season or with rain very concentrated in only a few months. Thus, a very irregular monthly and annual rainfall erosivity distribution can be observed. However, there are other climatic aspects that can also influence the rainfall regime, like anomalies linked to the Equatorial Pacific Ocean which
HESSD

8, 10707-10738, 2011

El-Niño southern oscillation and rainfall erosivity

C. R. Mello et al.

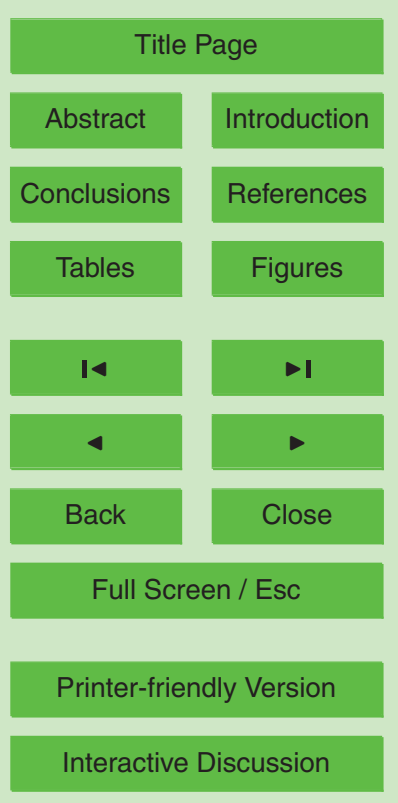


can accentuate the intra-annual variability. The El-Niño Southern Oscillation (ENSO) is one of the most important oceanic anomalies which influence the climate aspects on a large regional scale in a given year.

There are some meteorological indicators that can be associated to ENSO's which 5 are the Sea Surface Temperature (SST) in the Equatorial Pacific region and Multivariate ENSO Index (MEI). Both of these ENSO indicators can influence significantly rainfall distribution around the world (Ropelewski and Halpert, 1989; De Paula et al., 2010) and consequently, rainfall erosivity as well.

Current scientific investigations have searched to establish statistical relationships 10 between ENSO indicators and regional (or local) climatic characteristics. Nevertheless, these studies have been mainly associated with monthly rainfall and discharges from large basins (Chandimala and Zubair, 2007; Lü et al., 2011; Whitaker et al., 2011) and only a few have taken care to investigate how the rainfall erosivity can be affected by ENSO’s (Simpson et al., 1993; D‘Odorico et al., 2001).

15 The ENSO's variations have been well studied in recent years, and its behavior reasonably predicable. According to Whitaker et al. (2011), some ENSO's indexes can be forecasted up to 2-yr ahead. The search for relationships between ENSO indicators and rainfall behavior for a given region has been carried out with the objective of evaluating their potential in forecasting rainfall indicators (D'Odorico et al., 2001; Romero et al., 2007). This kind of a tool can be important for soil-water management on agricultural lands or mountainous regions since the latter environment has been associated to mudslide risks every summer, in Southeast/South Brazil.

The Alto Grande River Headwater Basin (AGHB) is located in Southern Minas Gerais State, Brazil, and corresponds to a headwater region of Grande River Basin. According to ANEEL (2005), the Grande River Basin is responsible for $16 \%$ of total amount of electric energy produced in Brazil and the Furnas Hydropower Plant the most important facility of the basin. Furnas' reservoir is fed directly by AGHB flow and is responsible for flow regularization in the lower Grande River basin (Nóbrega et al., 2011). In addition to this, specifically in the AGHB there are three Hydropower Plants working since the

\section{HESSD}

8, 10707-10738, 2011

El-Niño southern oscillation and rainfall erosivity

C. R. Mello et al.

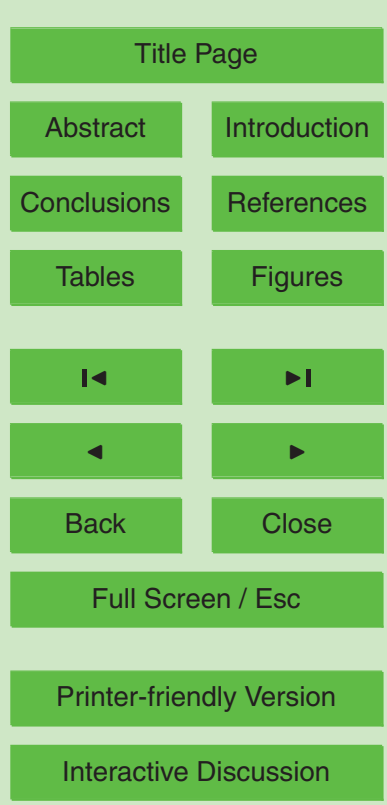


1960s, generating almost $200 \mathrm{MW}$. Thus, we can affirm that the AGHB is very important not only for energy production but also for hydrology and flow regularization into the Furnas reservoir.

The AGHB contains two specifically environments: Mantiqueira Range (MR) and 5 Plateau of South Minas Gerais (PSM). The first is responsible for Grande River springs and is present at elevations above sea level (a.s.l.) greater than $2300 \mathrm{~m}$ having mountainous and strong undulated relief. In the MR environment, there is not a good enough rainfall monitoring data for rainfall erosivity evaluation and only from 2006 was a more precisely temporal rainfall monitoring system installed for this purpose. The PSM en10 vironment can be characterized by rangelands associated with an elevation between 800-1200 m a.s.I. and it occupies the greatest part of Southern Minas Gerais State. For PSM, a complete monitoring was also implemented in 2006 although there are three official meteorological stations belonging to the "Instituto Nacional de Meteorologia" but more recent pluviographical data sets are not available. Because of this, we 15 have a serious problem to construct a long-term pluviographical data sets in the region which is indispensable for individual rainfall erosivity events evaluation.

According to Mello et al. (2008), the AGHB has presented substantial changes in land-use pattern, especially in the MR sub-region, in which extensive pasture has replaced Atlantic Forest. In the PSM sub-region, the land-use also has been changed in last decade, with expansion of Eucalyptus plantations instead of savanna and natural grasslands. These land-use changes, associated with changes in the rainfall regime and the influence of ENSO's (El-Niño and La-Niña episodes), can increase soil erosion risk in the AGHB (Beskow et al., 2009), thus increasing land degradation which can compromise the water resources in the basin and its hydropower generation potential. Based on this, the identification of some statistical relationships between ENSO's indexes and the rainfall erosivity in the AGHB becomes crucial for adequate soil-water management, giving support for the development of rainfall erosivity forecasting models.

\section{HESSD}

8, 10707-10738, 2011

El-Niño southern oscillation and rainfall erosivity

C. R. Mello et al.

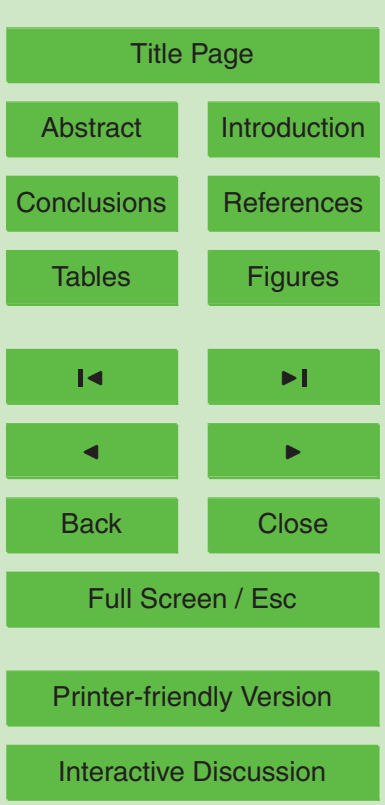


On the context described above, this work has the objective to investigate the rainfall erosivity behavior and to analyze statistical relationships between erosive rainfall variables and ENSO's indexes. The aim is to specifically understand how the Sea Surface Temperature (SST) and Multivariate ENSO Index (MEI) affect rainfall erosion for the 5 AGHB headwater region of Grande River Basin, Southern Minas Gerais state, Brazil.

\section{Materials and methods}

\subsection{Geographical location and basic characteristics of the Alto Grande River Headwater Basin (AGHB)}

The Alto Grande River Headwater Basin (AGHB) is located in Southern Minas Gerais 10 State, draining approximately $9000 \mathrm{~km}^{2}$ and is the headwater region of Grande River Basin (145000 km²), including parts from Minas Gerais and São Paulo States (Fig. 1). In the AGHB, there are two distinct sub-regions which are: Mantiqueira Range (MR) and Plateau of South Minas Gerais (PSM). The geographical location of the AGHB is presented in Fig. 1 as well as the meteorological automatic stations locations used in 15 this study.

According to Sparovek et al. (2007), the MR sub-region has a climate type Cwb by Köppen Procedure Classification, with mean annual precipitation about $2100 \mathrm{~mm}$, mean annual temperature near $15^{\circ} \mathrm{C}$. The PSM sub-region includes both $\mathrm{Cwb}$ and $\mathrm{Cwa}$ climatic types, depending on the elevation of each part of sub-region, with mean annual precipitation about $1500 \mathrm{~mm}$ and mean annual temperature around $18^{\circ} \mathrm{C}$. July and January are the coldest and warmest months, respectively, in both sub-regions. The mean temperature varies from 8 and $14^{\circ} \mathrm{C}$ and 18 and $21^{\circ} \mathrm{C}$ for MR and PSM, respectively. The same regional meteorological phenomena influence both sub-regions in terms of changes in rainfall regime. These phenomena are, basically, frontal systems, which act throughout the year, convective rainfall events are formed due to warming and humidity accumulated from the Amazonian region during the summer and spring seasons and

\section{HESSD}

8, 10707-10738, 2011

El-Niño southern oscillation and rainfall erosivity

C. R. Mello et al.

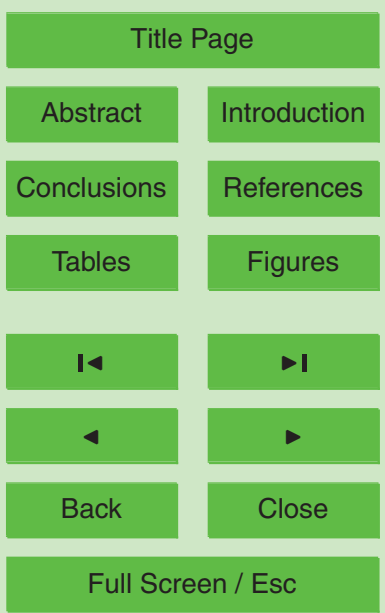

Printer-friendly Version

Interactive Discussion 
the SACZ. The ACSA is responsible for the dry season in Southeastern Brazil, acting during the autumn and winter seasons (Reboita et al., 2010). For both climatic types, the summer is characterized as rainy and with moderate temperature, including almost $80 \%$ of the total amount of rainfall and the winter is cool and much drier than the sum-

5 mer. Because of this, the summer season has the highest concentration of erosive rainfall events.

In MR sub-region, the soils predominant are Inceptisols and Litolic Neossol associated with strongly undulating and mountainous topographies, with mean slopeness greater than $45 \%$ in most of area and elevation above $1500 \mathrm{~m}$ a.s.l. (Araújo, 2006). 10 There is a significant presence of Oxissols and Inceptisols in PSM sub-region, with Fluvic Neossols associated with the drainage network. The mean slope is about $20 \%$ and elevations ranging from 800 to $1200 \mathrm{~m}$ a.s.l.

\subsection{Data sets and ENSO's indexes - rainfall erosivity relationships}

The rainfall data sets used in this study came from two Automatic Meteorological Sta15 tions, assembled in representative watersheds in each sub-region (see Fig. 1) and recording a value every $10 \mathrm{~min}$, since 2006 . In this study, we evaluated 434 and 336 rainfall events for, respectively, MR and PSM sub-regions from the period from January 2006 to December 2010. Pluviometric data sets are available for the region from the National Water Agency (ANA, 2010), however, they are not good enough for carrying 20 out a study related to the individual erosive rainfall events since they are recorded in daily intervals.

For this study, a given event was considered as when at least $3 \mathrm{~mm}$ rainfall depth had occurred separated by up to $6 \mathrm{~h}$. We used this criterion because $3 \mathrm{~mm}$ or less of precipitation does not promote significant changes in soil water budged. To eval-

uate whether a given rainfall event can be considered as erosive, two criteria were determined: the kinetic energy of rainfall greater than $3.6 \mathrm{MJ} \mathrm{ha}^{-1}$ and a rainfall depth greater than $12.5 \mathrm{~mm}$ during $10 \mathrm{~min}$ (Catari et al., 2011).

\section{HESSD}

8, 10707-10738, 2011

El-Niño southern oscillation and rainfall erosivity

C. R. Mello et al.

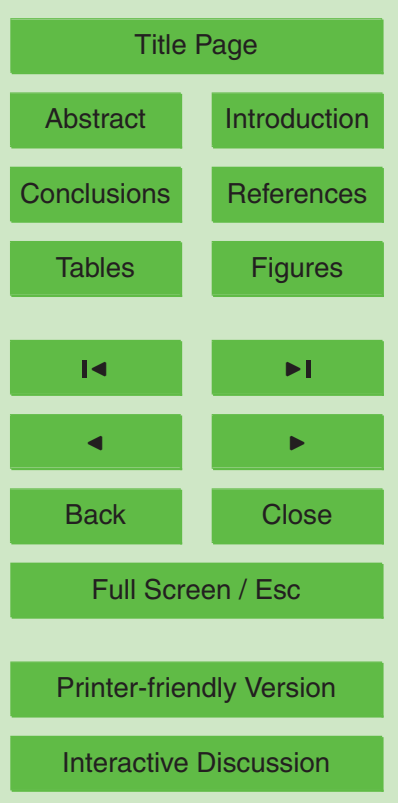


The rainfall kinetic energy was calculated using the equation recommended by Brown and Foster (1987):

$\mathrm{Ec}=0.29 \cdot[1-0.72 \cdot \exp (-0.05 \cdot /)]$

Where Ec is the rainfall kinetic energy $\left(\mathrm{MJ} \mathrm{ha}^{-1} \mathrm{~mm}^{-1}\right)$ and $/$ is the rainfall intensity $5\left(\mathrm{~mm} \mathrm{~h}^{-1}\right)$. These authors suggested this equation instead of the one from Wischmeier and Smith (1978) equation because it was adjusted using a better data base. The total kinetic energy of rainfall is obtained by:

$\mathrm{Ect}=\sum_{i=1}^{n} \mathrm{Ec}_{i} \times h_{i}$

Where Ect is the total rainfall kinetic energy $\left(\mathrm{MJ} \mathrm{ha}^{-1}\right), h_{i}$ is the rainfall depth $(\mathrm{mm})$, 10 in time interval $i$ and $n$ is the number of interval of rainfall. Finally, rainfall erosivity was estimated for every event considered erosive and was calculated according to Wischmeier and Smith (1978) definition:

$\mathrm{El}_{30}=\mathrm{Ect} \cdot \mathrm{I}_{30}$

Where $\mathrm{EI}_{30}$ is the rainfall erosivity for the event $\left(\mathrm{MJ} \mathrm{mm}(\mathrm{hah})^{-1}\right)$ and $I_{30}$ is the maxi15 mum rainfall intensity in a period of 30-min.

Rainfall erosivity $\left(\mathrm{El}_{30}\right)$, rainfall $(P)$ and erosive rainfall $(E)$ depths, erosive rainfall pattern, number of rainfall events (NRE), number of erosive rainfall events (NEE) and relation $E / P$ were the rainfall variables used to determine Pearson's coefficient of correlation. In terms of erosive rainfall pattern, we used the following procedure: the duration of rainfall was divided into three equal parts (33\% of the duration for each part); if the peak of intensity occurs in the first part (from 0 to $33 \%$ of duration), the rainfall is classified as "early pattern" (EP); in second part (from 33 to $66 \%$ of duration), "intermediate pattern" (IP) and in third part (from 66 to $100 \%$ of duration), "late pattern" (LP). Monthly Surface Sea Temperature (SST) and Multivariate ENSO Index (MEI) data sets were re- trieved from Climate Prediction Center of the US National Oceanic and Atmospheric 10714
HESSD

8, 10707-10738, 2011

El-Niño southern oscillation and rainfall erosivity

C. R. Mello et al.

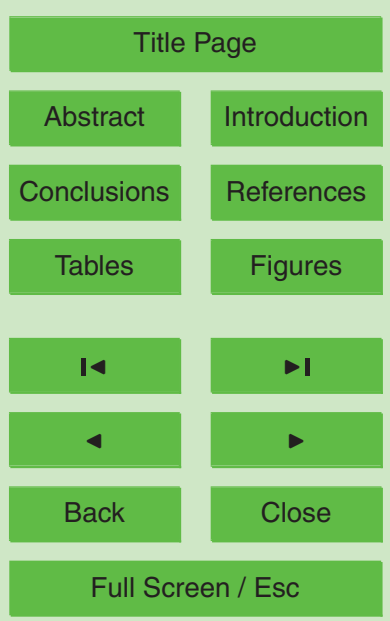

Printer-friendly Version

Interactive Discussion 
Administration (CPC, NOAA), on the web site www.cpc.noaa.gov/data/indices/soi. The SST values are associated to El Niño 3.4 , whose coordinates are $5^{\circ} \mathrm{N}-5^{\circ} \mathrm{S} ; 120^{\circ} \mathrm{W}-$ $170^{\circ} \mathrm{W}$, as this El Niño region exerts a greater influence on climatic conditions in Brazil than others (De Paula et al., 2010). The MEl data set was used in a monthly time 5 step although the data available are bi-monthly. For that, we followed the criterion recommended on the web site cited and MEI values were converted from bi-monthly to monthly considering the respective value as corresponded to the value for the last month of the bi-month, i.e., if a given MEI value is 1.2 for bi-month January /February, this value was used for February. Figure 2 shows the SST and MEI values from January 102006 to December 2010, being possible to identify the ENSO's phase throughout the period evaluated. We can verify that there was condition for two El-Niño episodes: between 2006-2007 of moderate intensity and 2009-2010 with a strong intensity. A moderate La-Niña formed between 2008 and 2009. However, the period between 2010 and 2011 was under a strong La-Niña.

15 Pearson's coefficient of correlation and "Student- $t$ " significance test were used for evaluating the existence of the relationship between monthly rainfall variables $\left(\mathrm{El}_{30}\right.$, $P, E$, NRE, NEE, EP, IP and LP) and SST and MEI. The correlation study was conducted taking into account positive and negative monthly oscillations separately, meaning trends in El-Niño and La-Niña episodes, respectively. These procedures were also used by Lü et al. (2011) and Chandimala and Zubair (2007) to evaluate the relationships between rainfall and discharge in headwater region of the Yellow River and in Sri-Lanka, respectively. D'Odorico et al. (2001) also studied the possible relationships between rainfall erosivity and ENSO's indexes for the Southwest US. The reason to use monthly values for correlations between SST and MEI values and erosive rainfall variables is because of the results from other authors, like De Paula et al. (2010). They tried to apply a specific EI-Niño indicator based on SST obtained from the moving average of three consecutive months, (known as Niño Oceanic Index - NOI), but found the relationships were not significant because for a given value of this indicator there were several values for rainfall erosivity.

\section{HESSD}

8, 10707-10738, 2011

\section{El-Niño southern oscillation and rainfall erosivity}

C. R. Mello et al.

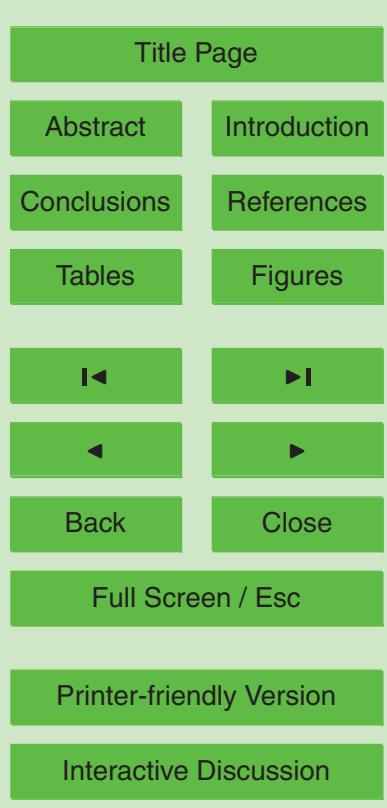


The purpose of the correlation study between erosive rainfall variables and MEI was to verify whether a multivariate ENSO indicator, based on more meteorological variables, can be used instead of SST or used combined with it. The MEl indicator is structured on the basis of 6 meteorological variables: surface sea temperature (SST), 5 air temperature, clouding, atmospheric pressure at sea level, meridian and zonal components of the surface wind (Wolter, 1987).

\section{Results and discussion}

\subsection{Rainfall erosivity behavior in the AGHB between 2006 and 2010}

Table 1 presents annual values of rainfall erosivity $\left(\mathrm{EI}_{30}\right)$ and rainfall depth $(P)$ for MR 10 and PSM sub-regions as well as mean annual values for SST during the period of monitoring (2006-2010). We can verify that a substantial intra-annual variability of $P$ which is well known due to climate characteristics of Southern Minas Gerais State (Reboita et al., 2010). The SACZ is an important phenomenon which generates a large amount of rainfall for Southeast Brazil, especially for the middle region of Minas Gerais State. 15 Although the SACZ has an effect the entire Southeast Brazil it has more influence in latitudes between $10-15^{\circ} \mathrm{S}$, especially in years characterized by stronger El-Niño episodes. This is according to Kodama (1992), who studied the convergence zones of the south Atlantic and the Pacific. Because of this Southern Minas Gerais State is affected by SACZ almost every year; however, its intensity is weaker than regions whose latitudes are closer to the Equator.

Using Foster's rainfall erosivity classification (Foster et al., 1981), the MR subregion can be classified as "very strong" due to mean annual erosivity greater than $9810 \mathrm{MJ} \mathrm{mm}(\text { ha h})^{-1} \mathrm{yr}^{-1}$. It is important to highlight that only one year (2007) had $\mathrm{El}_{30}$ lesser than the threshold for a"very strong" classification. Montebeller et al. (2007) and than 10000 and $12000 \mathrm{MJ} \mathrm{mm}(\text { ha h) })^{-1} \mathrm{yr}^{-1}$ for the Atlantic Range Region of Rio de

HESSD

8, 10707-10738, 2011

El-Niño southern oscillation and rainfall erosivity

C. R. Mello et al.

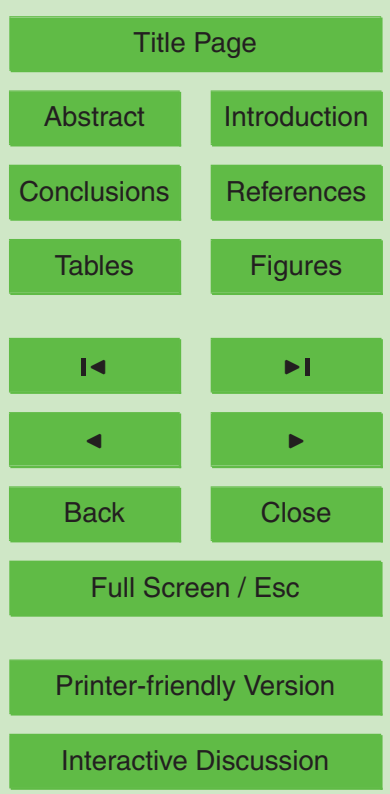

Interactive Discussion 
Janeiro State which is in the neighborhood of MR sub-region and has the same geomorphologic and climatic characteristics. These results demonstrate that the values found for the MR sub-region are close to the values obtained by other studies although a shorter term rainfall data set was used here.

For the PSM sub-region, the mean annual rainfall erosivity varied between 7357 and $9810 \mathrm{MJ} \mathrm{mm}(\mathrm{hah})^{-1} \mathrm{yr}^{-1}$, thus allowing us to classify it as a "strong" rainfall erosivity region. Nevertheless, we can also observe, in Table 1, an intra-annual variability greater than for the MR sub-region, with values varying from 3728 to $10199 \mathrm{MJ} \mathrm{mm}(\mathrm{ha} \mathrm{h})^{-1} \mathrm{yr}^{-1}$, generating classifications from "medium" to "very strong" 10 rainfall erosivity. Val et al. (1986) found for the Lavras region of Minas Gerais state, (located approximately $80 \mathrm{~km}$ from Meteorological Station 1 - PSM) a mean annual rainfall erosivity was $6837 \mathrm{MJ} \mathrm{mm}(\mathrm{hah})^{-1} \mathrm{yr}^{-1}$, while Aquino (2005), for the same place, found $5634 \mathrm{MJ} \mathrm{mm}$ (ha h) $)^{-1} \mathrm{yr}^{-1}$. The latter work used a longer and more recent pluviographical data set (from 1986 to 2004). Based on these results, which were estimated 15 for a region in the neighborhood and physically similar to PSM, the values found in this study are in good agreement and representative of this sub-region.

Although we used a short-term data set here (2006-2010), the mean annual rainfall values were similar to the value expected for both sub-regions. For MR and PSM subregions, the historical mean annual rainfall is about 2000 and $1500 \mathrm{~mm}$, respectively (Carvalho et al., 2008). Evaluating these values throughout the period analyzed for MR sub-region, we were able to verify that there was not a major outlier. However, for the PSM sub-region, the years of 2006 and 2007 can be considered as outliers, probably due to a global weather anomaly, like the ENSO. In both years, for the Lavras region, the annual rainfall recorded were, respectively, 1416 and $1248 \mathrm{~mm}$, demonstrating that the values found here are close to those obtained by another weather monitoring station in the region, confirming that the years 2006 and 2007 were outliers, and especially 2007, atypical of the PSM sub-region.

Figure 3 presents the mean annual ratio between $E$ and $P$ depths $(E / P)$, in percentage, for the sub-regions. For both, more than $70 \%$ of the rainfall depth occurs
HESSD

8, 10707-10738, 2011

El-Niño southern oscillation and rainfall erosivity

C. R. Mello et al.

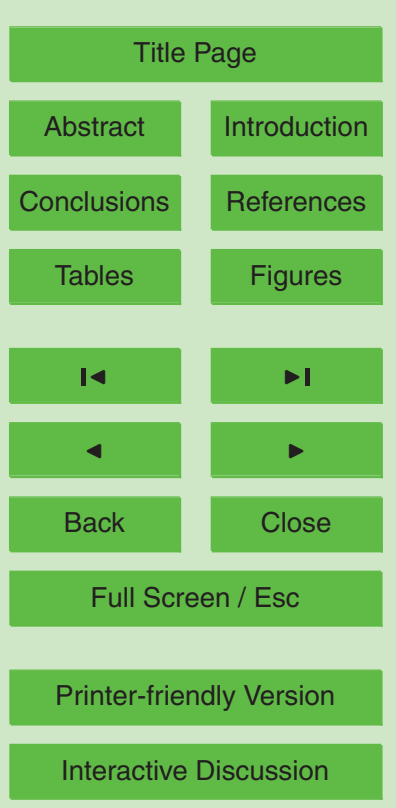


in erosive rainfall events. This behavior was associated with the topography of subregions contributing not only to soil erosion but also with the sediment transportation. Beyond this, it was possible to observe greater ratios in the MR sub-region for years of 2006 and 2007, showing that there was a greater amount of rainfall in erosive events 5 contributing to the total rainfall. This situation can be explained due to atypical years in PSM, as commented before, producing a total rainfall below the average in this subregion. In the other years, we can observe similar behavior of relationship for both sub-regions.

Tables 2 and 3 present data which contribute for understanding of rainfall's erosive 10 behavior in the MR and PSM sub-regions, respectively. We can see the same behavior throughout the year, in both sub-regions. However, comparing them, it's possible to observe some important differences. For the MR sub-region, the greatest $\mathrm{El}_{30}$ was obtained to January followed by December, November and February. For the PSM sub-region, December was the most erosive, followed by March and then January. 15 Aquino (2005), in her study about rainfall erosivity for the Lavras region, found a similar behavior, using a longer-term rainfall data set, charactering December as the most rainy and erosive month. Year 2009 was exceptionally rainy in the PSM during March, due to the presence of a SACZ. It's also important to mention that just one rainfall event generated erosivity of more than $3100 \mathrm{MJ} \mathrm{mm}(\mathrm{hah})^{-1}$. This rainfall anomaly was associated to increase in humidity convergence, i.e., the formation of a SACZ, reinforced by formation of low pressure nuclei adjacent to the coast (Infoclima, 2009).

Rainfall erosivity values have always been greater than in the MR sub-region, so have mean monthly and individual erosive rainfall events. During January 2006, in this

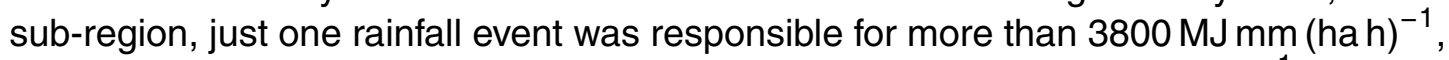
having the maximum rainfall intensity in $30-\min \left(I_{30}\right)$ greater than $140 \mathrm{~mm} \mathrm{~h}^{-1}$.

Monthly $\bar{E} / \bar{P}$ relationships have demonstrated the greatest values for the summer in both sub-regions. As the dry period begins, a reduction of this ratio occurs due to the predominance of rainfall from frontal systems during the winter which represents low intensity events with small rainfall depth, thus, reducing the erosive power of rain.
HESSD

8, 10707-10738, 2011

El-Niño southern oscillation and rainfall erosivity

C. R. Mello et al.

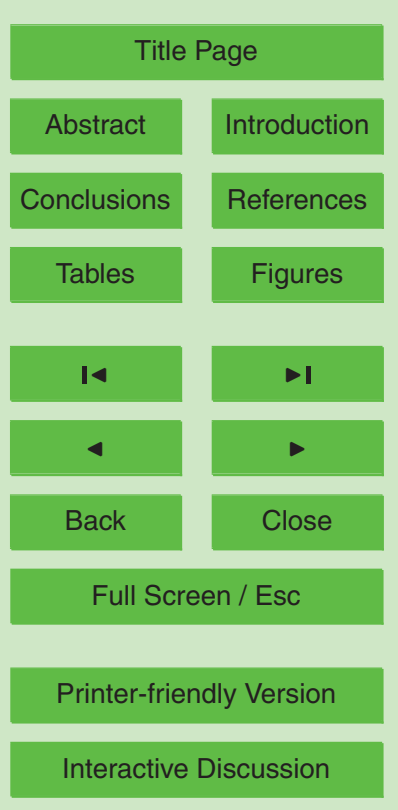

Interactive Discussion 
However, the reduction is greater in the PSM because, in the MR, the orographic effect is significant as well as its greater proximity of the coast, thus having more significant rainfall during the winter.

NRE, NEE and the erosive rainfall patterns (EP, LP and IP), in the sub-regions, are 5 presented in Table 4 . The NRE and NEE values are both approximately $22.6 \%$ greater in the MR. In terms of erosive rainfall patterns, there is a significant predominance of the early pattern (EP) in both sub-regions. This pattern is characterized by the occurrence of peak intensity in the first third of the rain event and it is probably associated with convective rainfall due to the physical process of cloud Cumulus formation. This 10 process is turbulent and instable and occurs under warming conditions which generates an over saturation of moisture in the atmosphere. This system moves toward an energy balance and, thus releases a great amount of rain quickly.

Proportionally, we found $55.4 \%$ and $53 \%$ of early pattern, followed by $25.4 \%$ and $24.8 \%$ of intermediate pattern, for the MR and PSM, respectively. Consequently, we 15 found only 21.8 and $22.1 \%$ for late pattern, respectively. Aquino (2005) found a similar frequency of rainfall patterns for the Lavras region, having $54.3 \%, 32.7 \%$ and $13 \%$ for early, intermediate and late patterns, respectively, demonstrating the predominance of this pattern for erosive rainfall events in this region.

\subsection{ENSO - erosive rainfall relationships}

20 Pearson's coefficients of correlation and Student- $t$ statistical test are presented in Table 5 for the variables related to erosive rainfall events. Previous studies in Brazil relating a statistical coefficient like Pearson's coefficient between annual rainfall erosivity and ENSO indicators are very rare. However, De Paula et al. (2010) developed a correlation study for the Santa Maria region of Rio Grande do Sul State, Brazil. They considered the NOI ENSO indicator, which is related to the El-Niño episodes, and annual rainfall erosivity but did not find significant results. These authors justified their results since for the ENSO indicator value there was more than one value for annual rainfall erosivity. Lü et al. (2011) who worked with monthly rainfall and mean discharge in the

\section{HESSD}

8, 10707-10738, 2011

El-Niño southern oscillation and rainfall erosivity

C. R. Mello et al.

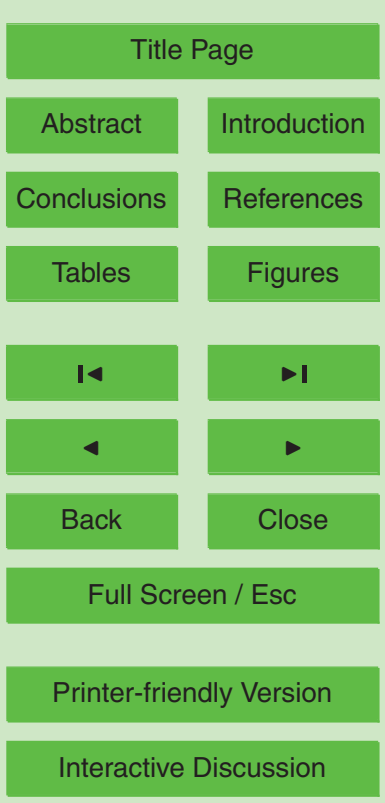


headwater region of the Yellow River, China, adopting monthly values of SST as an ENSO indicator and found significant correlations. D'Odorico et al. (2001), for Southwest US, found a significant coefficient of correlation between SST $>0$ and rainfall erosivity, using a similar methodology applied by Lü et al. (2011) which they adopted.

5 Another justification for applying this procedure in this study was related to the climatic behavior of the region studied. The hydrological year in south Minas Gerais state starts in September (or October) in a given year and ends in August (or September) of the next year. In addition, the rainy season corresponds to the summer and this period is responsible for almost $80 \%$ of total amount of rainfall during the hydrological 10 year. Based on these climatic aspects, a mean annual value does not capture the real behavior of the rainy season and, consequently, rainfall erosivity. This suggests that a monthly approach is more adequate for identification a possible connection between regional climate and global anomalies associated to the ENSO.

In that same context, we can see a gradual increasing in SST throughout of 2006, 15 culminating in a moderate El-Niño, thus producing an annual positive value for SST, however, close to that of a neutral year (Fig. 2 and Table 1). Nevertheless, the months from January to March of 2006 had rainfall below average and monthly values of SST are negative, indicating that there was negative correlation between SST and rainfall on these months which would have more weight on the annual rainfall. Using the same approach, the increasing in SST values can be related to the rainfall value recorded in both sub-regions in January of 2007 . For the PSM, $483 \mathrm{~mm}$ was recorded which corresponded to $40.1 \%$ of annual value for this year. In the MR sub-region, $632 \mathrm{~mm}$ was recorded, corresponding to the $34.3 \%$ of annual value. However, throughout of 2007, we verified an important decrease in the SST value which allowed characterizing 25 a moderate La-Niña for 2007-2008 Summer and in this year a rainfall value considerable below of the average was recorded. All of these aspects indicate that there is a monthly relationship between the erosive rainfall characteristics and SST, helping to justify the coefficients of correlation presented in Table 5.
HESSD

8, 10707-10738, 2011

El-Niño southern oscillation and rainfall erosivity

C. R. Mello et al.

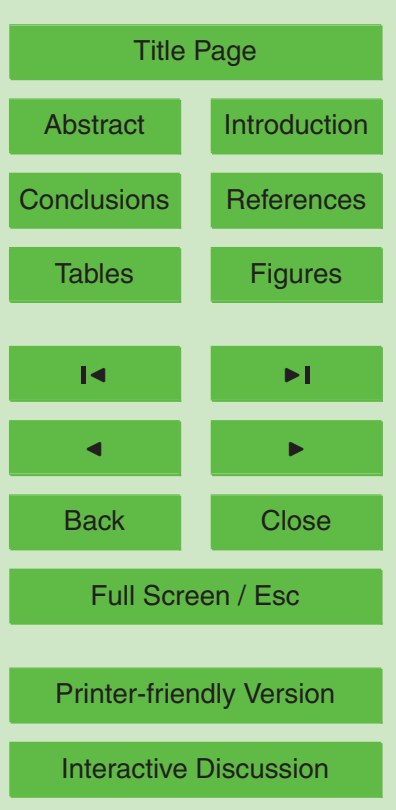


Regarding the correlations between SST and erosive rainfall variables, we can observe that the correlations were significant and negative, meaning that during SST negative oscillation (La-Niña episode), there will be a reduced number of rainfall events, rainfall depth and erosive rainfall power. The Pearson's coefficients were more signif5 icant for the MR so that the number of variables highly significant which means the La-Niñ a episodes have greater influence on rainfall behavior to the MR than PSM. Besides, monthly values of $\mathrm{El}_{30}$ were not significant in PSM under SST negative.

January, 2006 was atypical for the PSM in context of rainfall erosivity. Just one erosive rainfall event was measured which generated a monthly value about $1047.6 \mathrm{MJ} \mathrm{mm}(\mathrm{hah})^{-1}$. The SST value for this month was $-0.7^{\circ} \mathrm{C}$. Aquino (2005) also found for the Lavras region, in January, 2003, just one erosive rainfall event and a monthly $\mathrm{EI}_{30}$ value about $23 \mathrm{MJ} \mathrm{mm}$ (ha h) ${ }^{-1}$. The SST for this month/year had a value of $-0.3^{\circ} \mathrm{C}$ which was preceded by a December value of $-1.8^{\circ} \mathrm{C}$, indicating strong LaNiña episode in this season. These results indicate that although the Pearson's coefficient did not have a significant relationship between $\mathrm{El}_{30}$ and SST negative values for the PSM, there is evidence of an influence of La-Niña phenomenon in rainfall erosivity behavior in the AGHB.

Analyzing continuously the behavior of NRE and NEE as a function of SST (Fig. 4a), we can verify that there is a decrease for both variables following the SST behavior, especially for the 2007-2008 summer for the PSM sub-region. The SST values increased slightly throughout 2008, reaching neutral but reduced again in the 2008-2009 summer. Consequently, we can observe a reduction in NRE values for both regions. Grimm (2003), studying the El-Niño impact on summer rainfall in Brazil, found that rainfall diminishes in central-east of Brazil when negative oscillations of SST occurs. However, the negative oscillations of SST in this period are less and we do not have any situation of a strong La-Niña episode which would let us conclude more precisely about the relationship between negative SST and rainfall variables.

In context of the relationships between erosive rainfall variables and positive oscillations of SST, which indicates a trend toward El-Niño episodes, we can observe
HESSD

8, 10707-10738, 2011

El-Niño southern oscillation and rainfall erosivity

C. R. Mello et al.

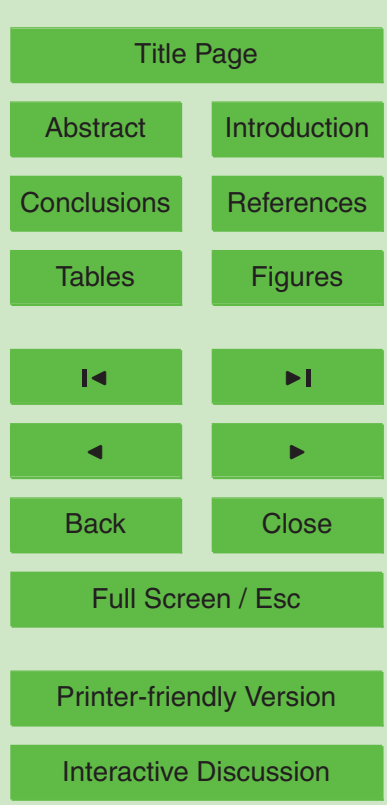


a positive Pearson's coefficients which are more significant than the coefficients obtained for relationships with negative oscillations of SST. These results mean that when SST indicates a positive oscillation, meaning trend toward El-Niño episodes, in both sub-regions, there is an increase in rainfall depth, rainfall erosivity, number of rainfall events and number of erosive rainfall events. As a result, we can expect rainfall events to be more erosive and consequently environmental problems will be more serious than during the seasons under negative oscillations of SST in the AGHB. These results are consistent with Haylock et al. (2006) who concluded that rainfall behavior in Southeastern Brazil is more connected to El-Niño episodes. Also, Carvalho et al. (2002), 10 studying the frequency of extreme rainfall in Southeastern Brazil, concluded that there were more extreme events during El-Niño conditions than La-Niña.

However, there are other atmospheric phenomena which have important influences on rainfall regimes of the sub-regions. For example: regarding the NEE and NRE frequency, especially for the later variable, there was an important increase in both values during 2008-2009 summer (January-March) but, during this period the SST oscillation was practically neutral $\left(0^{\circ} \mathrm{C}\right)$, meaning that SST did not exert influence on these variables for this summer. The explanation for that was the presence of the SACZ during this period, generating rainfall values above average, demonstrating that this phenomenon also exerts some control on the rainfall regime of region. Under neutral ENSO, SACZ has more control of the rainfall behavior in sub-regions.

Evaluating the Pearson's coefficients $(r)$ presented in Table 5, regarding the positive oscillations of SST obtained, we can observe greater coefficients than those obtained with negative oscillations of SST. Also, there are more variables whose relationships are highly significant. This aspect suggests that there is more influence of El-Niño episodes on the behavior of rainfall depth $(P)$, rainfall erosivity $\left(\mathrm{El}_{30}\right)$ and depth erosive rainfall $(E)$, in both sub-regions. However, the coefficients $(r)$ are greater in the MR than for PSM sub-region, having a significant correlation for early pattern of rainfall (EP). De Paula et al. (2010), for the Santa Maria region (RS), found a predominance of early pattern ( $56 \%$ of events) in relation to the La-Niña (52\% of events), interpreted as
HESSD

8, 10707-10738, 2011

El-Niño southern oscillation and rainfall erosivity

C. R. Mello et al.

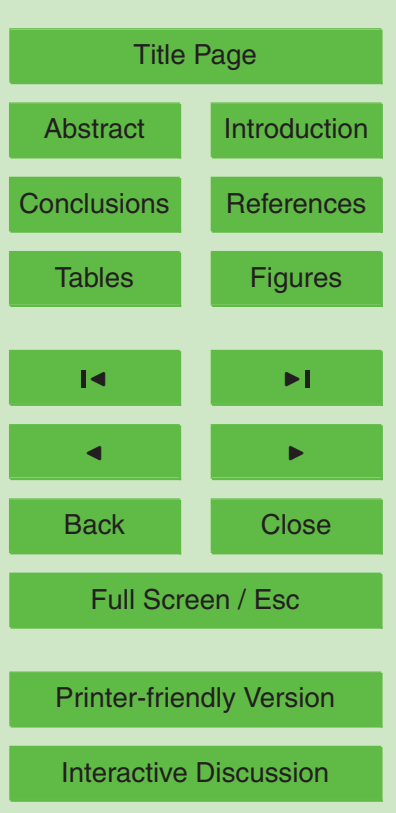


the influence of positive oscillations of SST on the behavior of rainfall. However, these authors did not obtain significant correlations.

For the rainfall erosivity variables tested, Pearson's Coefficients obtained for the PSM sub-region were greater than those obtained to MR sub-region when positive oscilla5 tions of SST were found. This behavior is possibly associated with the orographic effects which are much more significant for the MR sub-region. According to Nel et al. (2010), who studied the rainfall erosivity behavior in a mountainous region of South Africa, the altitude can promote better atmospheric conditions for cloud formation due to a lower vapor saturation pressure. These local and regional meteorological 10 aspects can mitigate the influence of remote anomalies. This aspect was also commented on by Grimm (2003) in her study of El-Niño impact on summer rainfall in Brazil.

Few rainfall significant events occur during the dry season, thus the relationships obtained are more important during the rainy season (October-April), independently of the SST oscillation. Lü et al. (2011), studying monthly rainfall behavior linked to 15 the SST on the headwater region of Yellow River, in China, also found important relationships only for the rainy season which occurs in the Chinese summer. They recommended the application of the relationships obtained mainly for forecasting of the rainfall during summer.

In Table 6 presents the Pearson's coefficients of correlation $(r)$ obtained between 20 the same rainfall variables presented in Table 5 and the Multivariate ENSO Index (MEI). This ENSO indicator is estimated on the basis of six meteorological elements for Equatorial Pacific Ocean and according to D'Odorico et al. (2001), its relationship with rainfall behavior needs to be evaluated because perhaps it is possible to obtain better relationships than with SST. We evaluated Pearson's coefficients significant for both sub-regions and found coefficients $(r)$ are lower than those obtained with the SST indicator, indicating that this ENSO index did not produce better relationships with erosive rainfall variables. This same aspect was observed by D'Odorico et al. (2001), who worked with possible correlations between ENSO indicators and rainfall erosivity, both in a monthly step, for the Southwest US, indicating that a given rainfall erosivity

\section{HESSD}

8, 10707-10738, 2011

El-Niño southern oscillation and rainfall erosivity

C. R. Mello et al.

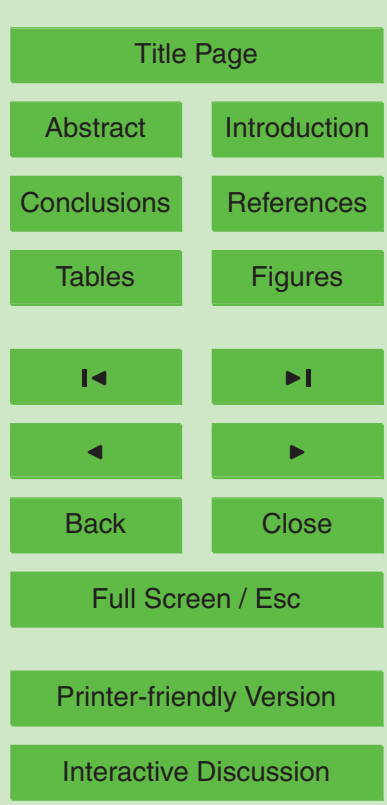


forecasting model can be better structured on the SST oscillations.

Although the short period of rainfall was evaluated in this study due to non-existence of the a good rainfall data bases for these regions, one of the possible applications of these results is linked to the development of rainfall erosivity forecasting models 5 based on ENSO indicators. We have demonstrated that there is an important relationship between erosive rainfall variables and SST and potentially the MEI ENSO indicator. These relationships were significant mainly for positive oscillations of SST, meaning that the greater the SST (or MEI) the greater rainfall erosivity. Authors like Lü et al. (2011), Chandimala and Zubair (2007) and D'Odorico et al. (2001) have con10 cluded the existence of relationships between the regional climate and ENSO indicators and about the potential of use them as a forecasting tool.

\section{Summary and conclusions}

This study evaluated relationships between rainfall erosivity $\left(\mathrm{El}_{30}\right)$, rainfall depth $(P)$, erosive rainfall depth $(E)$, number of rainfall events (NRE), number of erosive events 15 (NEE) and rainfall pattern (early, late and intermediate) and Sea Surface Temperature (SST) of the Equatorial Pacific region (Niño 3.4) and Multivariate ENSO Index (MEI), for the Alto Grande River Headwater Basin (AGHB) which corresponds to headwater region of the Grande River basin, in Minas Gerais state, Brazil. We used a pluviometric data sets from two automatic meteorological stations programmed for recording the

rainfall depth every $10 \mathrm{~min}$, in two different environments of the AGHB, specifically, the Mantiqueira Range (MR) and the Plateau of South Minas Gerais (PSM). Every rainfall event was evaluated in the period from January 2006 to December 2010 and the Pearson's Correlation Coefficient and Student- $t$ test was used in order to study the significant relationships.

25 This study was the first in Minas Gerais State to construct a pluviometric data sets to study rainfall erosivity due to the non-existence of a complete and precise rainfall monitoring in the region. Generally, there is not a longer pluviometric data set available
HESSD

8, 10707-10738, 2011

El-Niño southern oscillation and rainfall erosivity

C. R. Mello et al.

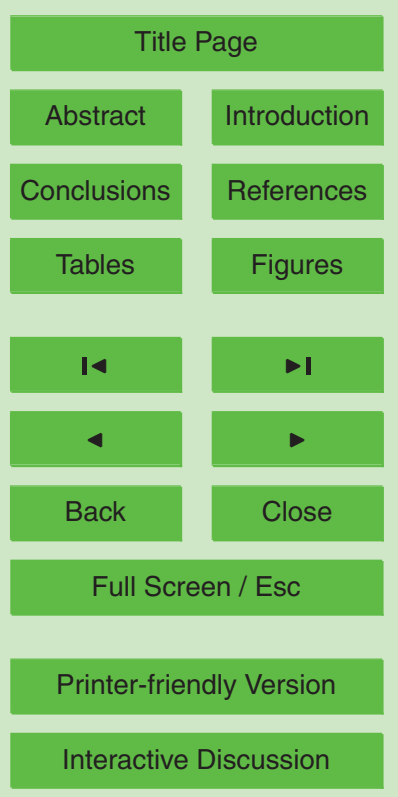


with the precision needed for rainfall erosivity purposes. The most important contribution of this paper is the linking of rainfall erosivity parameters with ENSO indicators for an important headwater region in Brazil.

The results obtained support a conclusion that the MR sub-region has a "very strong" 5 rainfall erosivity potential and the PSM sub-region, a "strong" potential, according to the classification proposed by Foster et al. (1981). Both sub-regions present strong intraannual variability of rainfall erosivity which is accentuated by the ENSO oscillations.

Pearson's correlation coefficients were highly significant between monthly erosive rainfall variables and SST positive oscillations in the AGHB, stressing the PSM sub10 region, which indicates that El-Niño episodes can produce a significant impact on rainfall erosivity behavior. Correlations with negative SST oscillations were also significant for the AGHB, especially for the MR sub-region, but lesser than those obtained when positive SST oscillations occurred. It's possible that the La-Niña phenomenon has lesser importance than El-Niño on the rainfall regime of region. The Pearson's correlations between erosive rainfall variables and the MEI ENSO indicator were also significant but lesser than those obtained for SST. However, for the MR sub-region, the coefficients were more significant than for the PSM sub-region.

\section{References}

ANA, Agência Nacional de Águas: HidroWeb - Sistema de Informações Hidrológicas, available at: http://hidroweb.ana.gov.br, last access: 1 December 2005, 2005.

ANEEL, Agência Nacional de Energia Elétrica: Brazilian Electric Energy Atlas, 2nd Edn., Brasília, 2005.

Aquino, R. F.: Rainfall patterns and spatial variability of erosivity for the South of Minas Gerais state, M.Sc. Thesis, Federal University of Lavras, Lavras, Brazil, 2005.

25 Araújo, A. R.: Soils of the Basin of the Grande River (MG): base for hydrological studies and agricultural sustainability, Ph.D. Thesis, Federal University of Lavras, Lavras, Brazil, 2006.

Barretto, A. G. O. P., Lino, J. S., and Sparovek, G.: Bibliometria da pesquisa brasileira em
HESSD

8, 10707-10738, 2011

El-Niño southern oscillation and rainfall erosivity

C. R. Mello et al.

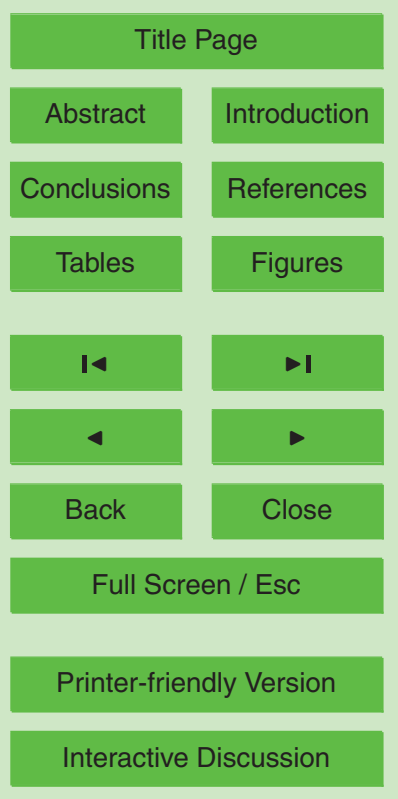


erosão acelerada do solo: instituições, temas, espaço e cronologia, R. Bras. Ci. Solo, 33, 1845-1854, 2009.

Beskow, S., Mello, C. R., Norton, D. L., Curi, N., Viola, M. R., and Avanzi, J. C.: Soil erosion prediction in the Grande River Basin, Brazil using distributed modeling, Catena, 79, 49-59, 52009.

Brown, L. C. and Foster, G. R.: Storm erosivity using idealized intensity distributions, T. ASAE, 30, 379-386, 1987.

Carvalho, L. G., Oliveira, M. S., Alves, M. C., Vianello, R. L., Sediyama, G. C., and Castro Neto, P.: Clima, in: Zoneamento Ecológico-Econômico do Estado de Minas Gerais: componentes geofísico e biótico, edited by: Scolforo, J. R., Carvalho, L. M. T., and Oliveira, A. D., Editora UFLA, Lavras, MG, Brazil, 9-102, 2008.

Carvalho, L. M. V., Jones, C., and Liebmann, B.: Extreme precipitation events in Southeastern South America and large-scale convective patterns in the South Atlantic convergence zone, J. Climate, 15, 2377-2394, 2002.

15 Catari, G., Latron, J., and Gallart, F.: Assessing the sources of uncertainty associated with the calculation of rainfall kinetic energy and erosivity - application to the Upper Llobregat Basin, NE Spain, Hydrol. Earth Syst. Sci., 15, 679-688, doi:10.5194/hess-15-679-2011, 2011.

Chandimala, J. and Zubair, L.: Predictability of stream flow and rainfall based on ENSO for water resources management in Sri Lanka, J. Hydrol., 335, 303-312, 2007.

D'Odorico, P., Yoo, J., and Over, T. M.: An assessment of ENSO-Induced Patterns of Rainfall Erosivity in the Southwestern United States, J. Climate, 14, 4230-4242, 2001.

De Paula, G. M., Streck, N. A., Zanon, A. J., Eltz, F. L. F., Heldwein, A. B., and Ferraz, S. E. T.: Influência do fenômeno El-Niño na erosividade das chuvas na região de Santa Maria (RS), Rev. Bras. Cienc. Solo, 34, 1315-1323, 2010.

25 Foster, G. R., McCool, D. K., Renard, K. G., and Moldenhauer, W. C.: Conversion of the Universal Soil Loss Equation to SI metric units, J. Soil Water Conserv., 36, 355-359, 1981.

Gonçalves, F. A., Silva, D. D., Pruski, F. F., Carvalho, D. F., Cruz, E. S., and Carvalho, D. F.: Índices e espacialização da erosividade das chuvas para o Estado do Rio de Janeiro, Rev. Bras. Engenharia Agr. Ambiental, 10, 269-276, 2006.

30 Grimm, A. M.: The El-Niño impact on the summer Monsoon in Brazil: regional processes versus remote influences, J. Climate, 16, 263-280, 2003.

Haylock, M. R., Peterson, T. C., Alves, L. M., Ambrizzi, T., Anunciação, Y. M. T., Baez, J., Barros, V. R., Berlato, M. A., Bidegain, M., Coronel, G., Corradi, V., Garcia, V. J., Grimm,

HESSD

8, 10707-10738, 2011

El-Niño southern oscillation and rainfall erosivity

C. R. Mello et al.

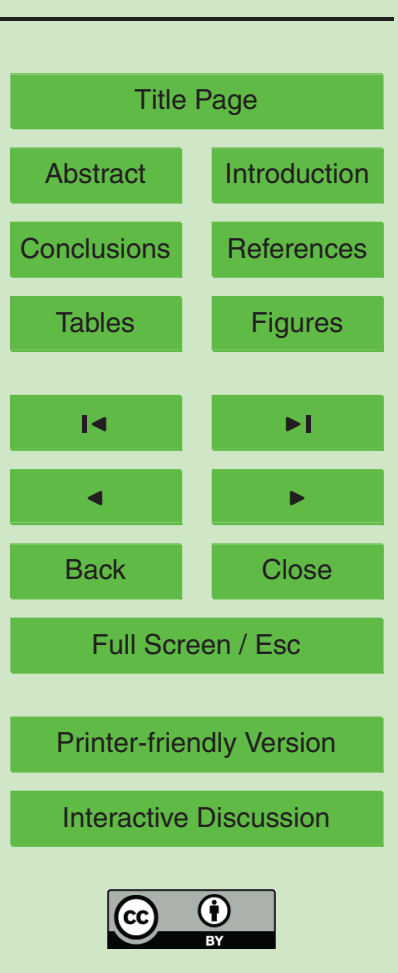


A. M., Karoly, D., Marengo, J. A., Marino, M. B., Moncunill, D. F., Nechet, D., Quintana, J., Rebello, E., Rusticucci, M., Santos, J. L., Trebejo, I., and Vincent, L. A.: Trends in total and extreme South American Rainfall in 1960-2000 and links with sea surface temperature, J. Climate, 19, 1490-1512, 2006.

5 INFOCLIMA: Boletim de Informações climáticas, 16(3), março/2009. available at: www.cptec. inpe.br/infoclima, last access: 1 July 2011, 2011.

Kodama, Y. M.: Large-scale common features of subtropical precipitation zones (the Baiu frontal zone, the SPCZ, and the SACZ), Part I: characteristics of subtropical frontal zones, J. Meteorol. Soc. Jpn., 70, 813-835, 1992.

10 Lü, A., Jia, S., Zhu, W., Yan, H., Duan, S., and Yao, Z.: El Niño-Southern Oscillation and water resources in the headwaters region of the Yellow River: links and potential for forecasting, Hydrol. Earth Syst. Sci., 15, 1273-1281, doi:10.5194/hess-15-1273-2011, 2011.

Mello, C. R., Viola, M. R., Norton, L. D., Silva, A. M., and Weimar, F. A.: Development and application of a simple hydrologic model simulation for a Brazilian headwater basin, Catena,

$15 \quad 75,235-247,2008$.

Mello, C. R., Sá, M. A. C., Curi, N., Mello, J. M., Viola, M. R., and Silva, A. M.: Erosividade mensal e annual da chuva no estado de Minas Gerais, Pesquisa Agropecuária Brasileira, 42, 537-545, 2007.

Montebeller, C. A., Ceddia, M. B., Carvalho, D. F., Vieira, S. R., and Franco, E. M.: Variabilidade espacial do potencial erosivo das chuvas no Estado do Rio de Janeiro, Engenharia Agrícola, 27, 426-435, 2007.

Nel, W., Reynhardt, D. A., and Sumner, P. D.: Effect of altitude on erosive characteristics of concurrent rainfall events in the Northern KwaZulu-Natal Drakensberg, Water SA 36, 509$512,2010$.

Nóbrega, M. T., Collischonn, W., Tucci, C. E. M., and Paz, A. R.: Uncertainty in climate change impacts on water resources in the Rio Grande Basin, Brazil, Hydrol. Earth Syst. Sci., 15, 585-595, doi:10.5194/hess-15-585-2011, 2011.

Reboita, M. S., Gan, M. A., Rocha, R. P., and Ambrizzi, T.: Regimes de precipitação na América do Sul: uma revisão bibliográfica, Rev. Bras. Meteorol., 25, 185-204, 2010.

30 Renard, K. G. and Freimund, J. R.: Using monthly precipitation data to estimate the $R$-factor in the revised USLE, J. Hydrol., 157, 287-306, 1994.

Romero, C. C., Baigorria, G. A., and Stroosnijder, L.: Changes of erosive rainfall for El-Niño and La-Niña years in the Northern Andean highlands of Peru, Climatic Change, 85, 343-

\section{HESSD}

8, 10707-10738, 2011

El-Niño southern oscillation and rainfall erosivity

C. R. Mello et al.

Title Page

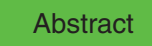

Introduction

Conclusions

Tables

References

Figures

14

$\rightarrow 1$

4

Back

Close

Full Screen / Esc

Printer-friendly Version

Interactive Discussion 
356, 2007.

Ropelewski, C. F. and Halpert, M. S.: Precipitation patterns associated with high index phases of southern oscillation, J. Climate, 2, 268-284, 1989.

Simpson, H. J., Cane, M. A., Herczeg, A. L., Zebiak, S. E., and Simpson, J. H.: Annual river 5 discharge in Southeastern Australia related to El-Niño southern oscillation forecasts of sea surface temperatures, Water Resour. Res., 29, 3671-3680, 1993.

Sparovek, G., van Lier, Q. J., and Dourado Neto, D.: Computer assisted Koeppen climate classification: a case study for Brazil, Int. J. Climatol., 27, 257-266, 2007.

Val, L. A., Bahia, V. G., Freire, J. C., and Dias Junior, M. S.: Erosividade das chuvas em Lavras, MG, Ciência e Prática, 10, 199-209, 1986.

Whitaker, D. W., Wasimi, S. A., and Islam, S.: The El-Niño southern oscillation and long-range forecasting of flows in the Ganges, Int. J. Climatol., 21, 77-87, 2011.

Wischmeier, W. H. and Smith, D. D.: Predicting Rainfall Erosion Losses: a Guide to Conservation Planning, USDA Agricultural Handbook, Washington, DC, 537, 1978.

15 Wolter, K.: The southern oscillation in surface circulation and climate over the tropical Atlantic, Eastern Pacific and Indian Oceans as captured by clusters analysis, J. Clim. Appl. Meteorol., 26, 540-558, 1987.

\section{HESSD}

8, 10707-10738, 2011

\section{El-Niño southern oscillation and \\ rainfall erosivity}

C. R. Mello et al.

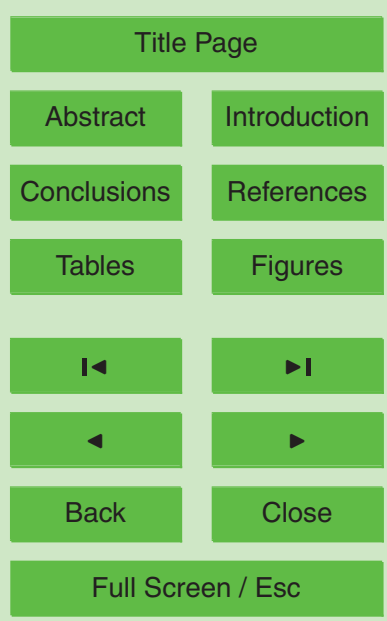

Printer-friendly Version

Interactive Discussion 


\section{HESSD}

8, 10707-10738, 2011

\section{El-Niño southern oscillation and rainfall erosivity}

Table 1. Annual rainfall erosivity and corresponded rainfall depth for the MR and PSM subregions (AGHB), Southern Minas Gerais State, Brazil.

\begin{tabular}{|c|c|c|c|c|c|}
\hline Year & $\begin{array}{r}\text { Mean SST } \\
\left({ }^{\circ} \mathrm{C}\right)\end{array}$ & $\begin{array}{r}\mathrm{MR} \\
\mathrm{EI}_{30} \\
\left(\mathrm{MJmm}\left(\mathrm{hah}^{-1}\right)\right.\end{array}$ & $\begin{array}{r}P \\
(\mathrm{~mm})\end{array}$ & $\begin{array}{r}\text { PSM } \\
\mathrm{EI}_{30} \\
\left(\mathrm{MJ} \mathrm{mm}\left(\mathrm{hah}^{-1}\right)\right.\end{array}$ & $\begin{array}{r}P \\
(\mathrm{~mm})\end{array}$ \\
\hline 2006 & 0.250 & 14588.61 & 2047 & 5428.39 & 1310 \\
\hline 2007 & -0.300 & 7940.16 & 1841 & 3728.25 & 1204 \\
\hline 2008 & -0.558 & 10330.28 & 2756 & 10199.43 & 1872 \\
\hline 2009 & 0.467 & 12585.20 & 2536 & 9560.82 & 1895 \\
\hline 2010 & -0.150 & 12899.67 & 2140 & 9647.89 & 1776 \\
\hline Mean & & 11668.78 & 2264 & 7712.96 & 1611 \\
\hline C.V. & & 0.221 & 0.165 & 0.380 & 0.204 \\
\hline
\end{tabular}

C. R. Mello et al.

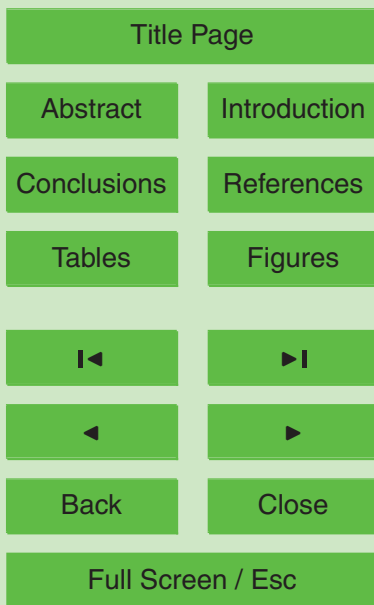

Printer-friendly Version

Interactive Discussion

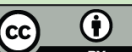




\section{HESSD}

8, 10707-10738, 2011

\section{El-Niño southern oscillation and \\ rainfall erosivity}

Table 2. Monthly erosive rainfall variables in the MR sub-region (AGHB), Southern Minas Gerais State, Brazil, for the period of 2006-2010.

\begin{tabular}{lrrrrrrr}
\hline Month & $\overline{\mathrm{El}}_{30}$ & $\begin{array}{r}\text { Greater monthly } \\
\mathrm{El}_{30}(\text { year) }\end{array}$ & $\begin{array}{r}\text { Greater individual } \\
\mathrm{El}_{30} \text { (year) }^{\mathrm{b}}\end{array}$ & $\mathrm{CV}_{\mathrm{El} 30 \mathrm{~m}}$ & $\begin{array}{r}\bar{P} \\
(\mathrm{~mm})\end{array}$ & $\mathrm{CV}_{\mathrm{Pm}}$ & $\left(\frac{\overline{\bar{E}}}{\bar{P}}, \%\right)$ \\
\hline Jan & 2624.68 & $4943.31(2006)$ & $3836.85(2006)$ & 0.542 & 397 & 0.342 & 81.56 \\
Feb & 1718.81 & $2726.8(2009)$ & $1682.61(2008)$ & 0.506 & 283 & 0.412 & 78.70 \\
Mar & 1387.63 & $2193.66(2009)$ & $1066.26(2010)$ & 0.482 & 270 & 0.418 & 79.32 \\
Apr & 590.43 & $1651.17(2006)$ & $1368.97(2006)$ & 1.166 & 129 & 0.614 & 62.64 \\
May & 107.38 & $274.93(2010)$ & $212.9(2010)$ & 1.026 & 51 & 0.202 & 51.97 \\
Jun & 15.79 & $78.97(2006)$ & $78.97(2006)$ & 2.236 & 21 & 0.470 & 17.92 \\
Jul & 57.31 & $144.84(2009)$ & $94.15(2009)$ & 1.069 & 29 & 0.785 & 60.69 \\
Aug & 114.09 & $473.42(2008)$ & $473.42(2008)$ & 1.799 & 38 & 1.194 & 55.56 \\
Sep & 278.89 & $446.57(2009)$ & $238.95(2010)$ & 0.383 & 87 & 0.489 & 69.95 \\
Oct & 1218.72 & $2455.41(2010)$ & $1053.59(2010)$ & 0.626 & 220 & 0.128 & 80.02 \\
Nov & 1769.25 & $2422.75(2010)$ & $1038.19(2010)$ & 0.334 & 350 & 0.175 & 83.95 \\
Dec & 1785.79 & $2710.73(2010)$ & $1169.47(2010)$ & 0.325 & 389 & 0.278 & 84.12 \\
\hline
\end{tabular}

C. R. Mello et al.

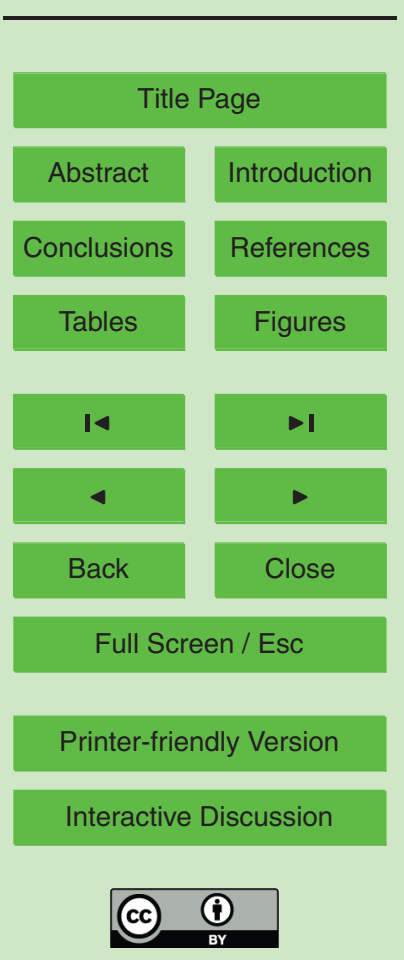




\section{HESSD}

8, 10707-10738, 2011

\section{El-Niño southern oscillation and \\ rainfall erosivity}

Table 3. Monthly erosive rainfall data in the PSM sub-region (AGHB), Southern Minas Gerais State, Brazil, in the period of 2006-2010.

\begin{tabular}{lrrrrrrr}
\hline Month & $\overline{\mathrm{El}}_{30}$ & $\begin{array}{r}\text { Greater monthly } \\
\mathrm{El}_{30}(\text { year) }\end{array}$ & $\begin{array}{r}\text { Greater individual } \\
\mathrm{El}_{30} \text { (year) }^{\mathrm{b}}\end{array}$ & $\mathrm{CV}_{\mathrm{El} 30 \mathrm{~m}}$ & $\begin{array}{r}\bar{P} \\
(\mathrm{~mm})\end{array}$ & $\mathrm{CV}_{\mathrm{Pm}}$ & $\left(\frac{\overline{\bar{E}}}{\bar{P}}, \%\right)$ \\
\hline Jan & 1389.05 & $2927.0(2010)$ & $1464.2(2010)$ & 0.860 & 286 & 0.503 & 83.94 \\
Feb & 1080.28 & $1630.9(2009)$ & $765.1(2009)$ & 0.580 & 183 & 0.432 & 79.41 \\
Mar & 1415.48 & $3611.9(2009)$ & $3177.0(2009)$ & 0.915 & 228 & 0.375 & 84.20 \\
Apr & 89.81 & $221.8(2008)$ & $173.1(2008)$ & 1.040 & 59 & 0.718 & 43.34 \\
May & 15.05 & $75.3(2007)$ & $75.3(2007)$ & 2.236 & 20 & 0.895 & 41.58 \\
Jun & 27.74 & $138.7(2009)$ & $75.4(2009)$ & 2.236 & 17 & 0.865 & 48.24 \\
Jul & 17.47 & $87.4(2010)$ & $87.4(2010)$ & 2.236 & 13 & 0.756 & 30.16 \\
Aug & 7.29 & $36.4(2009)$ & $36.4(2009)$ & 2.236 & 10 & 0.938 & 32.00 \\
Sep & 182.28 & $414.2(2009)$ & $283.4(2006)$ & 1.084 & 71 & 0.628 & 68.63 \\
Oct & 507.72 & $1303.3(2009)$ & $437.3(2009)$ & 0.899 & 146 & 0.330 & 67.49 \\
Nov & 966.74 & $1537.6(2006)$ & $1344.5(2006)$ & 0.504 & 229 & 0.345 & 67.10 \\
Dec & 2014.04 & $2443.9(2010)$ & $1490.6(2008)$ & 0.849 & 350 & 0.446 & 84.96 \\
\hline
\end{tabular}

C. R. Mello et al.

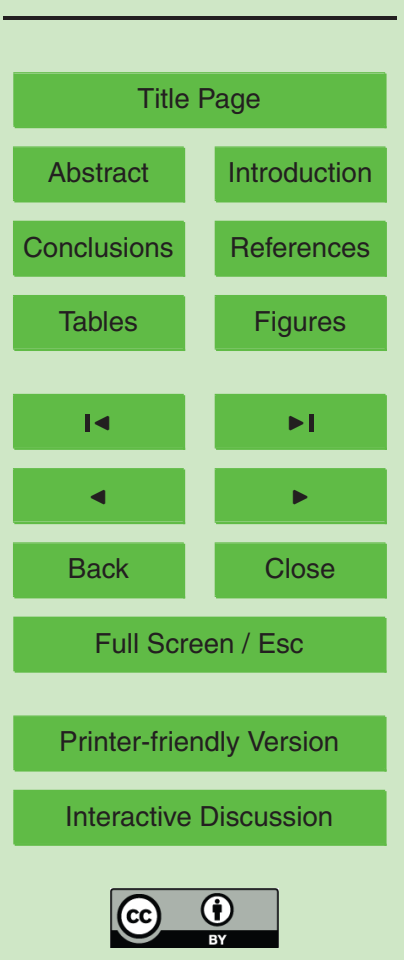




\section{HESSD}

8, 10707-10738, 2011

\section{El-Niño southern oscillation and}

Table 4. Number of Rainfall Events (NRE), Number of Erosive Events (NEE) and erosive rainfall patterns for the MR and PSM sub-regions (AGHB), Southern Minas Gerais State, Brazil, between 2006 and 2010.

\begin{tabular}{|c|c|c|c|c|c|c|c|c|c|c|}
\hline Month & NRE-MR & NRE-PSM & NEE-SR & NEE-PSM & EP-SR & EP-PSM & LP-SR & LP-PSM & IP-SR & IP-PSM \\
\hline Jan & 67 & 42 & 28 & 27 & 17 & 13 & 6 & 9 & 10 & 5 \\
\hline Feb & 59 & 41 & 26 & 20 & 16 & 9 & 5 & 5 & 5 & 6 \\
\hline Mar & 49 & 42 & 21 & 22 & 9 & 16 & 5 & 2 & 7 & 4 \\
\hline Apr & 35 & 17 & 10 & 5 & 7 & 3 & 1 & 1 & 2 & 1 \\
\hline May & 18 & 10 & 5 & 1 & 1 & 1 & 2 & 0 & 2 & 0 \\
\hline Jun & 11 & 10 & 1 & 2 & 0 & 1 & 0 & 0 & 1 & 1 \\
\hline Jul & 10 & 6 & 4 & 1 & 2 & 0 & 0 & 0 & 2 & 1 \\
\hline Aug & 9 & 6 & 3 & 1 & 1 & 1 & 0 & 0 & 2 & 0 \\
\hline Sep & 24 & 17 & 10 & 8 & 6 & 2 & 1 & 2 & 3 & 4 \\
\hline Oct & 43 & 38 & 22 & 16 & 16 & 11 & 5 & 3 & 1 & 2 \\
\hline Nov & 59 & 54 & 37 & 20 & 18 & 10 & 6 & 5 & 13 & 5 \\
\hline Dec & 50 & 53 & 26 & 26 & 14 & 12 & 11 & 6 & 1 & 8 \\
\hline Total & 434 & 336 & 193 & 149 & 107 & 79 & 42 & 33 & 49 & 37 \\
\hline
\end{tabular}

C. R. Mello et al.

\section{Title Page}

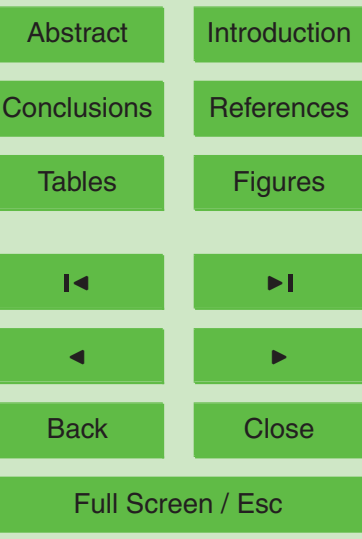

Printer-friendly Version

Interactive Discussion 


\section{HESSD}

Table 5. Pearson's Correlation Coefficient between monthly SST and erosive rainfall variables in the MR and PSM sub-regions (AGHB), between 2006 and 2010.

\begin{tabular}{|c|c|c|c|c|}
\hline SST $<0$ correlations & $r(\mathrm{MR})$ & $|t|$ value & $r$ (PSM) & $|t|$ value \\
\hline $\mathrm{El}_{30}$ & $-0.402^{*}$ & 0.0203 & $-0.267^{\mathrm{ns}}$ & 0.134 \\
\hline Number of Rainfall Events (NRE) & $-0.503^{\star \star}$ & 0.0029 & $-0.395^{\star}$ & 0.0227 \\
\hline Number of Erosive Events (NEE) & $-0.472^{*}$ & 0.0221 & $-0.506^{\star *}$ & 0.0026 \\
\hline Rainfall depth $(P)$ & $-0.545^{\star *}$ & 0.0011 & $-0.473^{*}$ & 0.0305 \\
\hline Erosive rainfall depth $(E)$ & $-0.544^{\star \star}$ & 0.0011 & $-0.484^{*}$ & 0.0257 \\
\hline Early Rainfall Pattern (EP) & $-0.386^{*}$ & 0.0448 & $-0.208^{\mathrm{ns}}$ & 0.245 \\
\hline Late Rainfall Pattern (LP) & $-0.292^{\mathrm{ns}}$ & 0.119 & $-0.223^{\mathrm{ns}}$ & 0.213 \\
\hline Intermediate Rainfall Pattern (IP) & $0.061^{\mathrm{ns}}$ & 0.606 & $-0.262^{n s}$ & 0.139 \\
\hline SST $>0$ correlations & $r(\mathrm{MR})$ & $|t|$ value & $r$ (PSM) & $|t|$ value \\
\hline $\mathrm{El}_{30}$ & $0.699^{\star *}$ & 0.00014 & $0.721^{\star \star}$ & 0.00007 \\
\hline Number of Rainfall Events (NRE) & $0.664^{\star \star}$ & 0.00041 & $0.716^{\star \star}$ & 0.00008 \\
\hline Number of Erosive Events (NEE) & $0.675^{\star \star}$ & 0.00012 & $0.704^{\star *}$ & 0.0003 \\
\hline Rainfall depth $(P)$ & $0.668^{\star \star}$ & 0.00036 & $0.703^{* *}$ & 0.00013 \\
\hline Rainfall depth erosive $(E)$ & $0.660^{\star \star}$ & 0.00045 & $0.675^{\star *}$ & 0.00054 \\
\hline Early Rainfall Pattern (EP) & $0.478^{*}$ & 0.0182 & $0.738^{\star *}$ & 0.00004 \\
\hline Late Rainfall Pattern (LP) & $0.072^{\text {ns }}$ & 0.737 & $0.306^{\text {ns }}$ & 0.146 \\
\hline Intermediate Rainfall Pattern (IP) & $-0.179^{\mathrm{ns}}$ & 0.403 & $0.297^{\text {ns }}$ & 0.158 \\
\hline
\end{tabular}

El-Niño southern oscillation and rainfall erosivity

C. R. Mello et al.

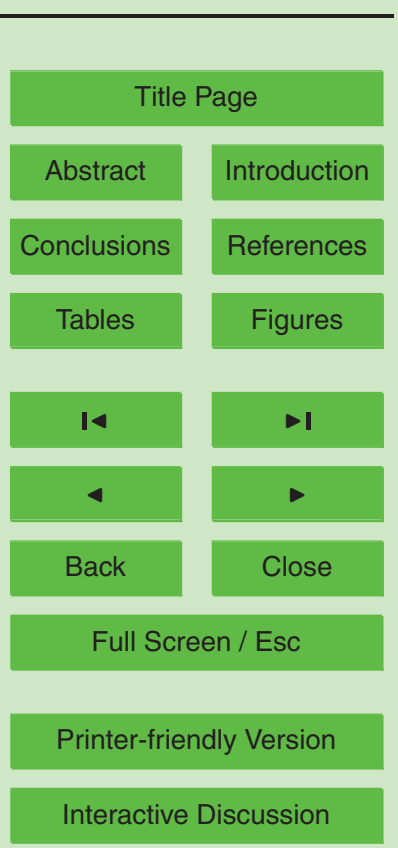




\section{HESSD}

Table 6. Pearson's Correlation Coefficient between MEI ENSO indicator and erosive rainfall variables in the MR and PSM sub-regions (AGHB), between 2006 and 2010.

\begin{tabular}{|c|c|c|c|c|}
\hline $\mathrm{MEI}<0$ correlations & $r(\mathrm{MR})$ & $|t|$ value & $r(\mathrm{PSM})$ & $|t|$ value \\
\hline $\mathrm{El}_{30}$ & $-0.317^{+}$ & 0.064 & $-0.192^{\mathrm{ns}}$ & 0.269 \\
\hline Number of Rainfall Events (NRE) & $-0.363^{\star}$ & 0.0321 & $-0.320^{+}$ & 0.061 \\
\hline Number of Erosive Events (NEE) & $-0.404^{*}$ & 0.016 & $-0.348^{*}$ & 0.041 \\
\hline Rainfall depth $(P)$ & $-0.434^{\star}$ & 0.010 & $-0.382^{*}$ & 0.023 \\
\hline Erosive rainfall depth $(E)$ & $-0.449^{\star *}$ & 0.007 & $-0.382^{*}$ & 0.023 \\
\hline Early Rainfall Pattern (EP) & $-0.250^{\mathrm{ns}}$ & 0.147 & $-0.215^{\mathrm{ns}}$ & 0.215 \\
\hline Late Rainfall Pattern (LP) & $-0.365^{\star}$ & 0.031 & $-0.062^{\mathrm{ns}}$ & 0.724 \\
\hline Intermediate Rainfall Pattern (IP) & $0.329^{+}$ & 0.054 & $-0.249^{\mathrm{ns}}$ & 0.149 \\
\hline $\mathrm{MEI}>0$ correlations & $r$ & $|t|$ value & $r$ & $|t|$ value \\
\hline $\mathrm{El}_{30}$ & $0.524^{\star *}$ & 0.0071 & $0.444^{*}$ & 0.026 \\
\hline Number of Rainfall Events (NRE) & $0.479^{\star}$ & 0.0155 & $0.449^{\star}$ & 0.025 \\
\hline Number of Erosive Events (NEE) & $0.520^{\star *}$ & 0.0077 & $0.453^{\star}$ & 0.023 \\
\hline Rainfall depth $(P)$ & $0.501^{*}$ & 0.0108 & $0.497^{\star}$ & 0.011 \\
\hline Erosive rainfall depth $(E)$ & $0.487^{*}$ & 0.0135 & $0.465^{\star}$ & 0.019 \\
\hline Early Rainfall Pattern (EP) & $0.273^{\text {ns }}$ & 0.187 & $-0.009^{\text {ns }}$ & 0.968 \\
\hline Late Rainfall Pattern (LP) & $0.235^{\mathrm{ns}}$ & 0.257 & $0.386^{+}$ & 0.065 \\
\hline Intermediate Rainfall Pattern (IP) & $0.424^{*}$ & 0.035 & $0.202^{\mathrm{ns}}$ & 0.332 \\
\hline
\end{tabular}

El-Niño southern oscillation and rainfall erosivity

C. R. Mello et al.

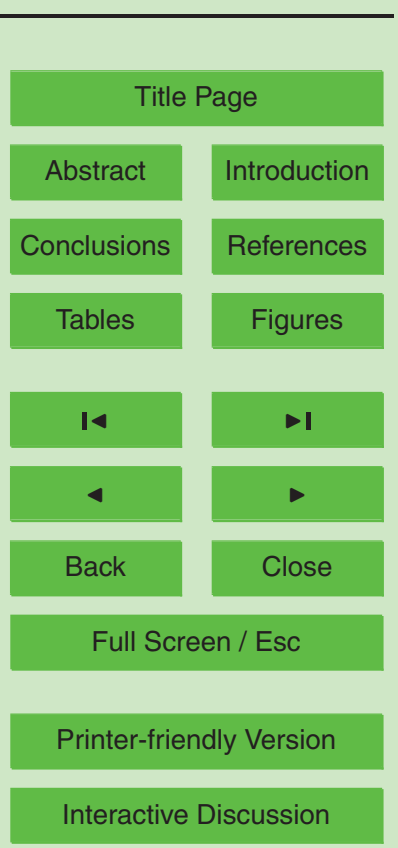


HESSD

8, 10707-10738, 2011

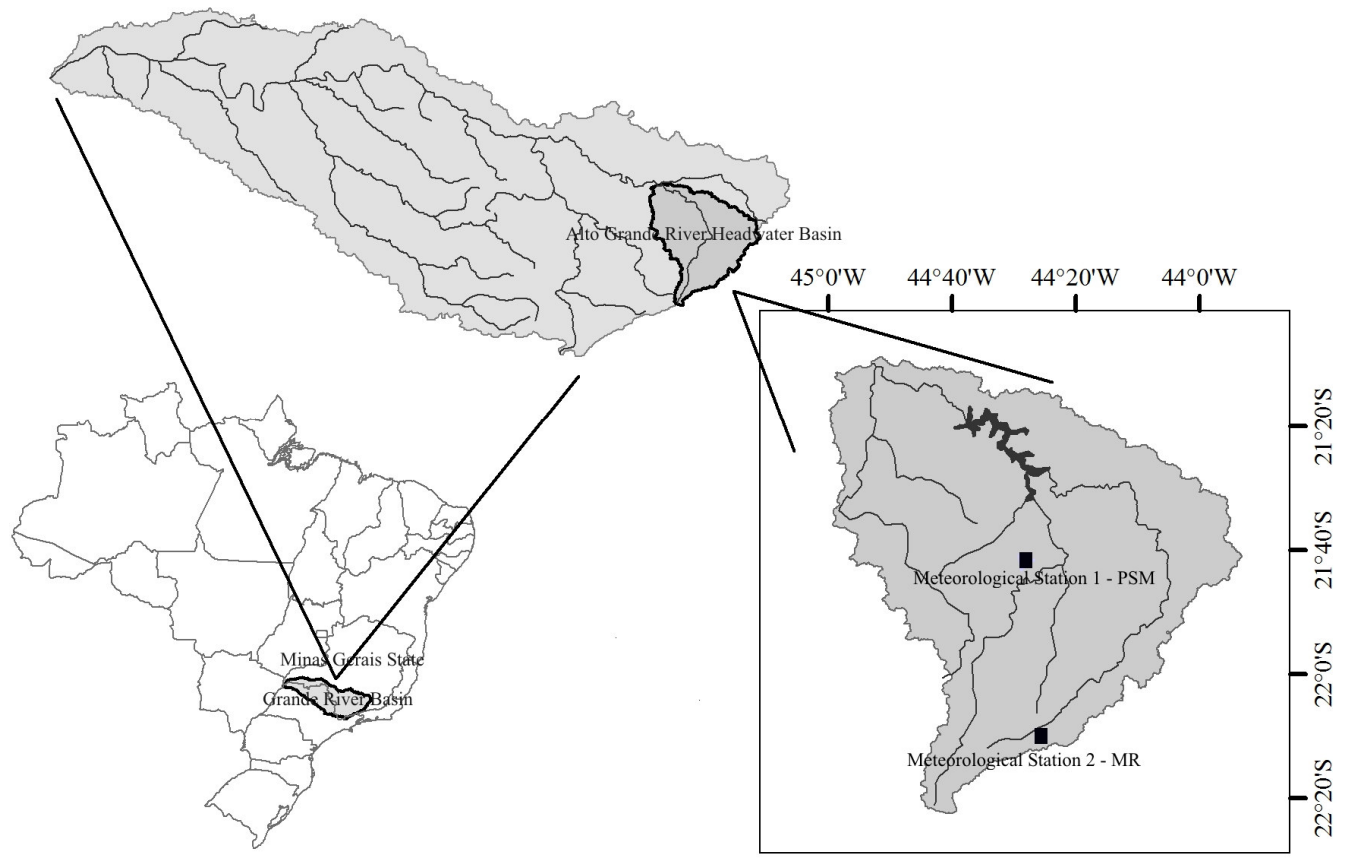

\section{El-Niño southern oscillation and rainfall erosivity}

C. R. Mello et al.

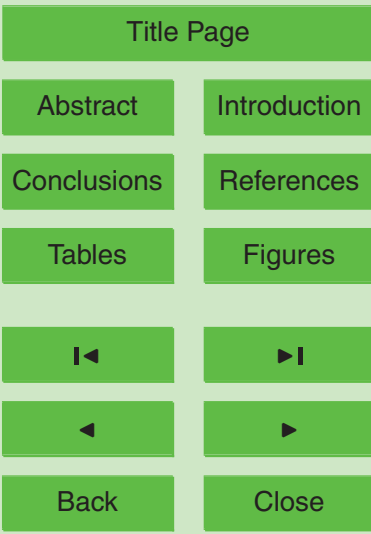

Fig. 1. The geographic location of the AGHB and the location of the meteorological automatic stations used in this study.

\section{Full Screen / Esc}

Printer-friendly Version

Interactive Discussion 


\section{HESSD}

8, 10707-10738, 2011

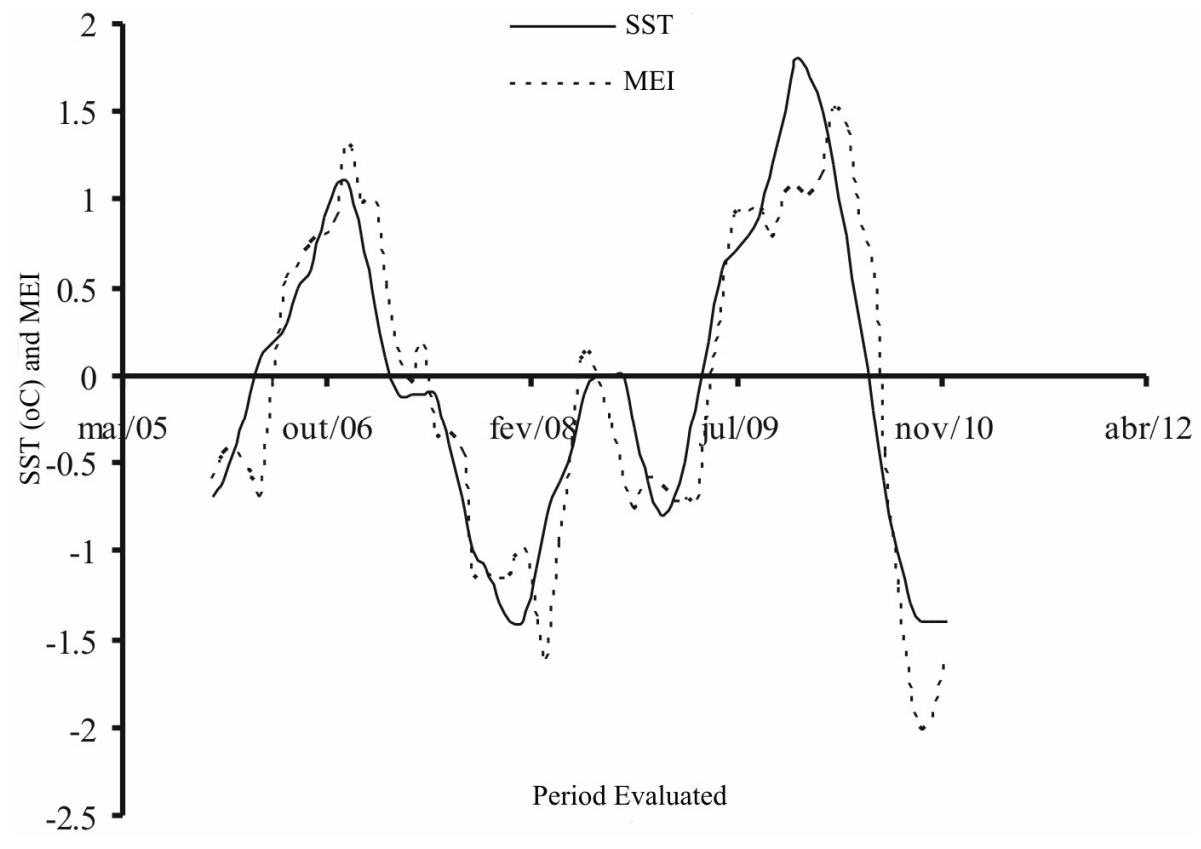

\section{El-Niño southern oscillation and rainfall erosivity}

C. R. Mello et al.

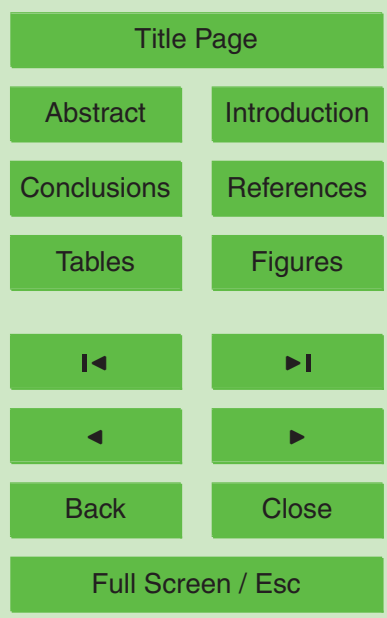

Fig. 2. SST and MEI ENSO's indexes for Niño 3.4 between January 2006 and December 2010 (CPC, NOAA). 


\section{HESSD}

8, 10707-10738, 2011

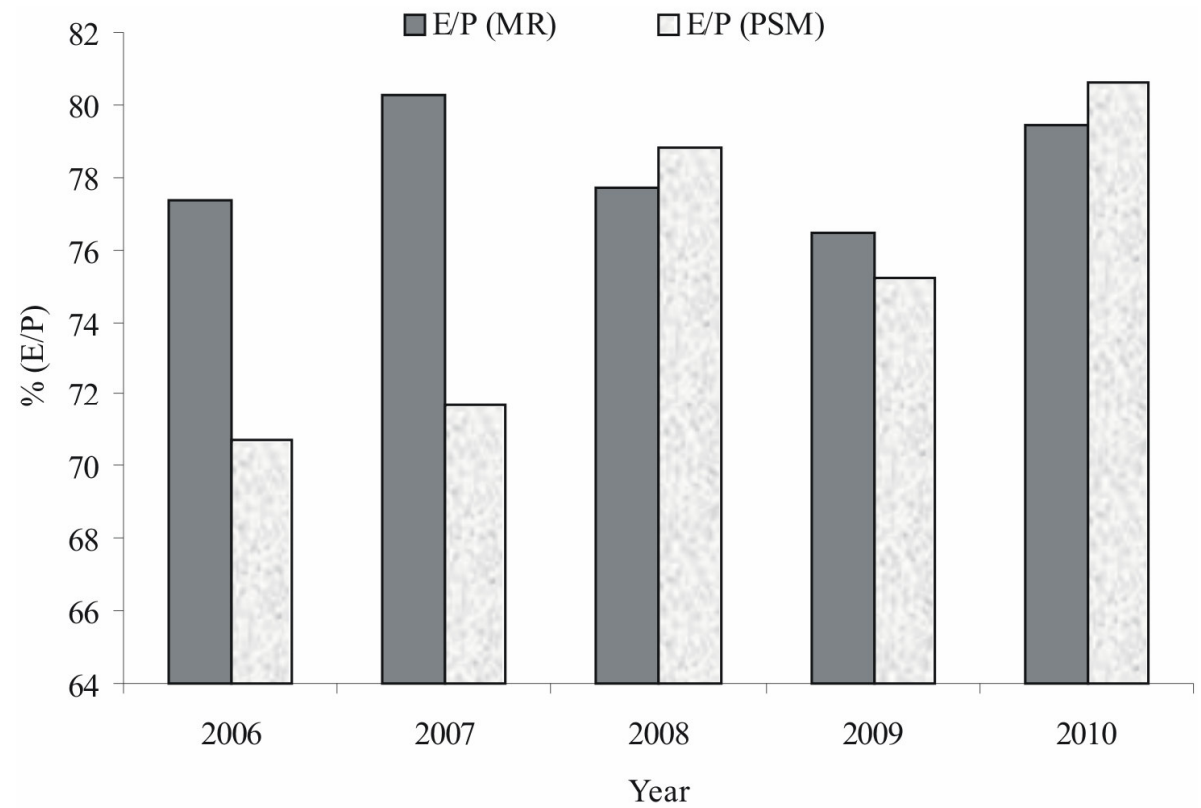

\section{El-Niño southern oscillation and rainfall erosivity}

C. R. Mello et al.

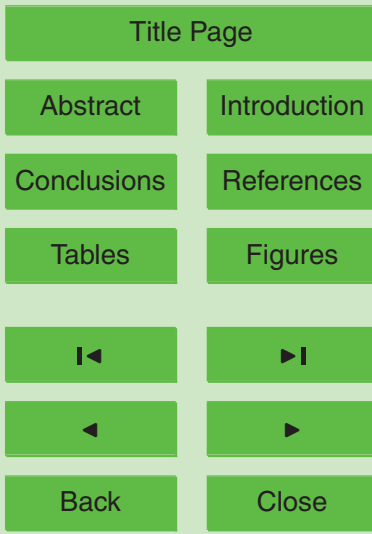

Fig. 3. Mean annual ratio between $E$ and $P$ depths, in percentage, for SM and PSM sub-regions (AGHB), Southern Minas Gerais State, Brazil.

\section{Full Screen / Esc}

Printer-friendly Version

Interactive Discussion 

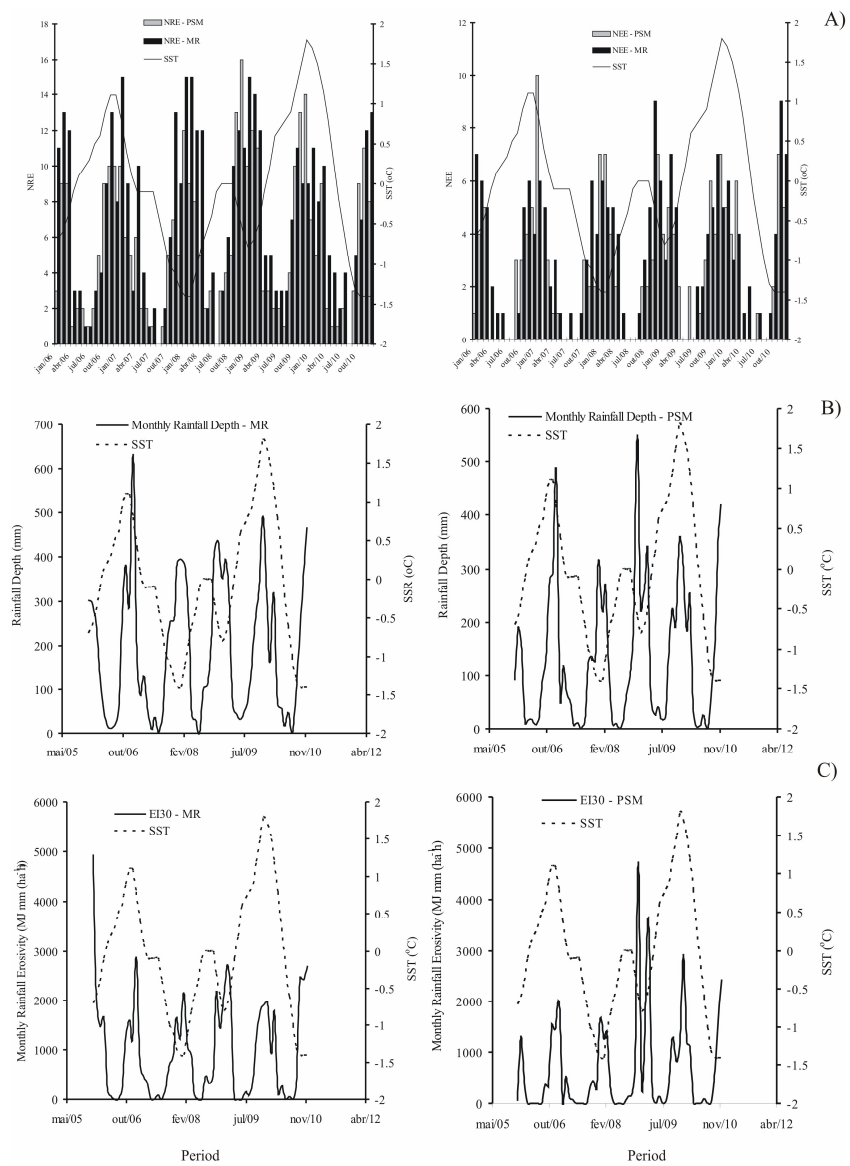

Period

Fig. 4. Monthly erosive rainfall variables against monthly SST ((A) NRE and NEE; (B) monthly rainfall depth; (C) monthly rainfall erosivity) for the MR and PSM sub-regions (AGHB), Southern of Minas Gerais State, Brazil.

\section{HESSD}

8, 10707-10738, 2011

\section{El-Niño southern oscillation and rainfall erosivity}

C. R. Mello et al.

\section{Title Page}

Abstract

Introduction

Conclusions

References

Tables

Figures

I

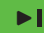

4

Back

Close

\section{Full Screen / Esc}

Printer-friendly Version

Interactive Discussion 